\title{
Assessment of climate impacts on the karst-related carbon sink in SW China using MPD and GIS
}

Sibo Zeng ${ }^{\mathrm{a}, \mathrm{b}} \cdot$ Yongjun Jiang $^{\mathrm{a}, \mathrm{b}^{*}} \cdot$ Zaihua Liu $^{\mathrm{c}^{*}}$

${ }^{a}$ School of Geographical Sciences, Southwest University, Chongqing 400715, China

${ }^{\mathrm{b}}$ Karst Environment Laboratory, Southwest University, Chongqing 400715, China

${ }^{\mathrm{c}}$ State Key Laboratory of Environmental Geochemistry, Institute of Geochemistry, Chinese Academy of Sciences, Guiyang 550081, China

* Corresponding author. Tel: +86 2368253446 (YJ); +86 85185895263 (ZL).

E-mail address: jiangjyj@swu.edu.cn (YJ); liuzaihua@vip.gyig.ac.cn (ZL). 
Abstract Riverine carbon fluxes of some catchments in the world have significantly changed due to contemporary climate change and human activities. As a large region with an extensive karstic area of nearly $7.5 \times 10^{5} \mathrm{~km}^{2}$, Southwest (SW) China has experienced dramatic climate changes during recent decades. Although some studies have investigated the karst-related carbon sink in some parts of this region, the importance of climate impacts have not been assessed. This research examined the impacts of recent climate change on the karst-related carbon sink in the SW China for the period 1970-2013, using a modified maximal potential dissolution (MPD) method and GIS. We first analyzed the major determinants of carbonate dissolution at a spatial scale, calculated the total karst-related carbon sink (TCS) and carbon sink fluxes (CSFs) in the SW China karst region with different types of carbonate rocks, and then compared with other methods, and analyzed the causes of CSFs variations under the changed climate conditions. The results show that the TCS in SW China experienced a dramatic change with regional climate, and there was a trend with TCS decreasing by about $19 \%$ from 1970s to 2010s. This decrease occurred mostly in Guizhou and Yunnan provinces, which experienced larger decreases in runoff depth in the past 40 years $(190 \mathrm{~mm}$ and $90 \mathrm{~mm}$, respectively) due to increased air temperature $\left(0.33{ }^{\circ} \mathrm{C}\right.$ and $1.04{ }^{\circ} \mathrm{C}$, respectively) and decreased precipitation (156 mm and $106 \mathrm{~mm}$, respectively). The mean value of CSFs in SW China, calculated by the modified MPD method, was approximately $9.36 \mathrm{t} \mathrm{C} \mathrm{km}^{-2} \mathrm{a}^{-1}$. In addition, there were large differences in CSFs among the provinces, attributed to differences in regional climate and to carbonate lithologies. These spatiotemporal changes depended mainly on hydrological variations (i.e., discharge or runoff depth). This work, thus, suggests that the karst-related carbon sink could respond to future climate change quickly, and needs to be considered in the modern global carbon cycle model.

Keywords: Karst-related carbon sink; Climate change; MPD; GIS; SW China 


\section{Introduction}

Atmospheric $\mathrm{CO}_{2}$ plays a significant role in controlling global climate. The established global carbon cycle models, however, cannot balance the atmospheric $\mathrm{CO}_{2}$ budget, leaving a so-called "missing carbon sink" problem (Tans et al., 1990; Melnikov and O'Neill, 2006). Finding the missing carbon sink is becoming one of the most important questions in the research of global climate change. Although the weathering of silicate minerals can capture atmospheric $\mathrm{CO}_{2}$ by forming $\mathrm{HCO}_{3}{ }^{-}$from continent to oceans (Berner et al., 1983; Berner, 1992), this carbon sink is limited due to the slow weathering kinetics of silicate minerals over short time scales (Liu et al., 2011). Carbonate rock is the world's biggest carbon reservoir, and the rapid kinetics of carbonate dissolution result in a large amount of atmospheric $\mathrm{CO}_{2}$ consumption (Yuan et al., 1997; Liu and Zhao, 2000; Gombert, 2002; Liu et al., 2010; Liu et al., 2011). Furthermore, according to a new conceptual model of the carbon sink produced by $\mathrm{H}_{2} \mathrm{O}$-carbonate- $\mathrm{CO}_{2}$-aquatic phototroph interaction, this carbon sink produced by carbonate weathering can be transferred by aquatic organisms and buried as organic matter (Liu and Dreybrodt, 2015). Therefore, carbonate weathering coupled with aquatic photosynthesis are a significant potential mechanism for the terrestrial missing carbon sink (Liu and Dreybrodt, 2015).

The increase in atmospheric $\mathrm{CO}_{2}$ has resulted in remarkable contemporary global climate change (Friedlingstein et al., 2006, Gedney et al., 2006), but the carbon sink produced by chemical weathering of rocks has been considered to be unchanged since pre-industrial times in global carbon models (Sabine et al., 2004). However, recent investigations have found evidence that contemporary climate change is accelerating the chemical weathering rate and altering the relevant carbon fluxes (Raymond and Cole, 2003; Macpherson et al., 2008; Raymond et al., 2008; Gislason et al., 2009). Duo to the high sensitivity of carbonate weathering to environmental change (Liu et al., 2007; Yang et al., 2012), the response of this 
carbon sink may be rapid and considerable (Liu and Dreybrodt, 2015; Zeng et al., 2016). For instance, Raymond et al. (2008) and Raymond and Cole (2003) attributed a proximately 20\% increase of alkalinity $\left(\mathrm{HCO}_{3}{ }^{-}+\mathrm{CO}_{3}{ }^{2-}\right.$ ) (increasing from $20.3 \mathrm{mg} / \mathrm{l}$ to $25.4 \mathrm{mg} / \mathrm{l}$ ) in the Mississippi River during the past half-century to a $9 \%$ increase in precipitation. Macpherson et al. (2008) found a $20 \%$ increase in groundwater $p \mathrm{CO}_{2}$ and $13 \%$ increased alkalinity between 1990 and 2005 in the karst area of Konza Prairie, USA, due to the increasing atmospheric $\mathrm{CO}_{2}$ and perhaps atmospheric temperature. An experimental air $\mathrm{CO}_{2}$ enrichment study in Duke Forest also indicated that an elevated atmospheric $\mathrm{CO}_{2}$ experiment of $200 \mathrm{ppm}$ $(+50 \%)$ in two years led to $33 \%$ increase in alkalinity of ground water duo to accelerating chemical weathering (Andrews and Schlesinger, 2001). Therefore, it is problematic that the conventional assumption that pre- and post- anthropogenic riverine carbon fluxes are the same (Sabine et al., 2004), and it is necessary to quantify the strength of the feedback of the karst-related carbon sink to changed climate conditions worldwide.

Many methods have been used to calculate the global karst-related carbon sink, including the DBL (Diffusion Boundary Layer) model (Liu and Zhao, 2000) and the MPD (Maximal Potential Dissolution) formula (Gombert, 2002). The MPD formula is a theoretical method based on climatic parameters. The calculations of MPD could be a powerful tool when used to estimate karst-related carbon sink perturbations due to changed climate conditions (Gombert, 2002). On the other hand, consideration of carbonate lithologies (limestone and dolomite) in estimating the karst-related carbon sink in a large karstic area is critical, due to their different solubilities (Dreybrodt, 1988).

The primary objective of this paper is to assess the karst-related carbon sink response to the changed climate over the past 40 years in SW China, where there is a high percentage $(\sim 43 \%)$ of karstic area with different carbonate lithologies and there is a monsoonal climate, using the MPD and GIS. 


\section{Study area}

The study area is situated in SW China $\left(20^{\circ} 54^{\prime}-34^{\circ} 19^{\prime} \mathrm{N}, 97^{\circ} 21^{\prime}-116^{\circ} 08^{\prime}\right.$ E) (Fig.1), covering approximately $17.6 \times 10^{5} \mathrm{~km}^{2}$ and including seven provinces: Sichuan, Chongqing, Hubei, Yunnan, Guizhou, Hunan and Guangxi. The northwestern and eastern sides of the study area are bordered by the Tibet Plateau and the Central China Plain, respectively, and thus the altitude is higher in the west (Fig 1). The karst region of SW China is well known for its extensive carbonate rock outcrop and intensive karst landform development. Plateaus, mountains and plains are the main landform types in the region, and the area is characterized by typical monsoonal climate. Annual precipitation in the area is about $1,148 \mathrm{~mm}$, most of which falls in the monsoon season from April to September. The mean annual air temperature in SW China is about $15.4^{\circ} \mathrm{C}$, with hot summers (June-August) and cold winter (December-February) (http://cdc.cma.gov.cn).

\section{(Fig.1 here)}

\section{Methods}

\subsection{Data collection}

The distribution of karst in SW China was extracted from maps of soluble rock types in China, as edited by Institute of Karst Geology, Chinese Academy of Geological Sciences (1985). By calculation and classification, the karst region in SW China covers an area of approximate $7.5 \times 10^{5} \mathrm{~km}^{2}$ and the main lithologies include limestone, dolomite, mixed limestone/dolomite and impure carbonate rocks mixed with clays or other silicate minerals (Fig. 2). The areas underlain by karst in each province are shown in Table 1. 


\section{(Fig. 2 here) (Table 1 here)}

Daily meteorological data, including precipitation $(P, \mathrm{~mm})$, mean temperature $\left(T_{\text {mean }},{ }^{\circ} \mathrm{C}\right)$, insolation duration $(n, \mathrm{~h})$, mean humidity $\left(R H_{\text {mean }}, \%\right)$, and mean wind speed $(W S, \mathrm{~m} / \mathrm{s})$, in 240 stations in and around the SW China from 1970 to 2013 (data from 1981, 1982 and 1984 are missing) (station locations are shown on Fig.1), were obtained from the China Meteorological Data Sharing Service System (http://cdc.cma.gov.cn).

\subsection{Maximal potential dissolution (MPD) method}

Many methods can be used to calculate the carbonate dissolution rate. However, most of these methods need long-term field measurements or complicated parameters which are difficult to obtain, which makes it difficult to estimate the response of the karst-related carbon sink to climate change in a large karst area. To solve these problems, Gombert (2002) created a theoretical method optimizing carbonate dissolution processes called Maximal Potential Dissolution (MPD). The intensity of karstification and the relevant carbon sink can be obtained by the MPD method, if air temperature, precipitation, evapotranspiration are known in the given area.

Gombert (2002) gave the usual equation for dissolution of calcite at equilibrium:

$$
\mathrm{CaCO}_{3}+\mathrm{CO}_{2}+\mathrm{H}_{2} \mathrm{O} \leftrightarrow \mathrm{Ca}^{2+}+2 \mathrm{HCO}_{3}^{-}
$$

The equation equilibrium constant $K^{*}$ can be expressed as:

$$
K^{*}=\left(\mathrm{Ca}^{2+}\right)\left(\mathrm{HCO}_{3}^{-}\right)^{2} /\left(\mathrm{CO}_{2}\right)=K_{\mathrm{s}}\left(K_{1} / K_{2}\right),
$$

where parentheses correspond to activities; $K_{1}$ is the equilibrium constant of the $\mathrm{CO}_{2}$ hydration and dissociation with the formation of $\mathrm{HCO}_{3}^{-} ; K_{2}$ is the equilibrium constant of 
$\mathrm{CO}_{3}{ }^{2-}$ formation; and $K_{\mathrm{S}}$ is the calcite solubility constant. The value of $\left(\mathrm{CO}_{2}\right)$ can be obtained by using Henry's law:

$$
\left(\mathrm{CO}_{2}\right)=K_{0} p \mathrm{CO}_{2}
$$

where $\mathrm{K}_{0}$ is the equilibrium constant of $\mathrm{CO}_{2}$ dissolution in water, and $p \mathrm{CO}_{2}$ is the partial pressure of $\mathrm{CO}_{2}$ inside the soil or aquifer.

When the reaction maintains equilibrium, we have:

$$
2\left[\mathrm{Ca}^{2+}\right]=\left[\mathrm{HCO}_{3}^{-}\right]
$$

$K^{*}$ is thus:

$$
K^{*}=4\left[\mathrm{Ca}^{2+}\right] /\left(\mathrm{K}_{0} p \mathrm{CO}_{2}\right)=\mathrm{K}_{\mathrm{s}}\left(\mathrm{K}_{1} / \mathrm{K}_{2}\right)
$$

Hence, at $\mathrm{CaCO}_{3}$ saturation, $\mathrm{Ca}^{2+}$ concentrations can be expressed as:

$$
\left[\mathrm{Ca}^{2+}\right]_{\mathrm{eq}}=\left(K_{\mathrm{s}} K_{1} K_{0} / 4 K_{2}\right)^{1 / 3}\left(p \mathrm{CO}_{2}\right)^{1 / 3}
$$

MPD's mathematical formulation of the maximal theoretical dissolution flux $\left(\mathrm{mol} \mathrm{km} \mathrm{k}^{-2} \cdot \mathrm{a}^{-1}\right)$ incorporates this equilibrium calcite dissolution with climate parameters:

$$
D_{\max }=10^{6}(P-E)\left[\mathrm{Ca}^{2+}\right]_{\mathrm{eq}}=10^{6}(P-E)\left(K_{\mathrm{s}} K_{1} K_{0} / 4 K_{2} \gamma_{\mathrm{Ca}} \gamma_{\mathrm{HCO}_{3}}\right)^{1 / 3}\left(p \mathrm{CO}_{2}\right)^{1 / 3}
$$

where $\mathrm{P}$ is the total precipitation $(\mathrm{mm} / \mathrm{a}) ; \mathrm{E}$ is the evapotranspiration $(\mathrm{mm} / \mathrm{a}) ;\left[\mathrm{Ca}^{2+}\right]_{\mathrm{eq}}$ is the concentration of calcium for calcite at equilibrium; $\gamma_{\mathrm{Ca}}, \gamma_{\mathrm{HCO} 3}$ are activity coefficients of $\mathrm{Ca}^{2+}$ and $\mathrm{HCO}_{3}^{-}$in water, respectively.

The dissolution of each mole of $\mathrm{CaCO}_{3}$ consumes one mole $\mathrm{CO}_{2}$. Thus, according to MPD, the karst-related carbon sink fluxes can be calculated by the following equation:

$$
\begin{aligned}
& C S F \mathrm{~s}=10^{6}(P-E)\left[\mathrm{HCO}_{3}{ }^{-}\right]_{\mathrm{eq}} / 2=10^{6}(P-E)\left[\mathrm{Ca}^{2+}\right]_{\mathrm{eq}} \\
& =10^{6}(P-E)\left(K_{\mathrm{s}} K_{1} K_{0} / 4 K_{2} \gamma_{\mathrm{Ca}} \gamma_{\mathrm{HCO}^{2}}\right)^{1 / 3}\left(p \mathrm{CO}_{2}\right)^{1 / 3}
\end{aligned}
$$

The annual total carbon sink (TCS, $\left.\mathrm{t} \mathrm{C} \mathrm{a}^{-1}\right)$ in a given karst area can then be expressed as follow equation:

$$
T C S=6 D S\left[\mathrm{HCO}_{3}^{-}\right]_{\mathrm{eq}}
$$

where $D$ is the runoff depth $(P-E)(\mathrm{m} / \mathrm{a}), S$ is the land surface area underlain by karst $\left(\mathrm{km}^{2}\right)$, 
and $\left[\mathrm{HCO}_{3}{ }^{-}\right]_{\mathrm{eq}}$ is the concentration of bicarbonate for calcite at equilibrium $(\mathrm{mmol} / \mathrm{L})$.

\subsection{An extension of MPD method to other type of carbonates}

In natural conditions, other types of carbonates than calcite also exist. Dolomite is $21 \% \sim 38 \%$ more soluble than calcite at temperatures between 0 and $30^{\circ} \mathrm{C}$ (Fig. 3, Dreybrodt, 1988; Liu et al., 2007), indicating that the carbonate lithology may play a significant role in controlling the size of the karst-related carbon sink flux. In order to distinguish the differences in equilibrium concentration between multiple types of carbonates, an equilibrium concentration calculating software EQILCAMG (Dreybrodt, 1988) was used to determine the ratio of the moles of calcite and dolomite that will dissolve at equilibrium $\left[\mathrm{C}(\mathrm{eq})_{\mathrm{D}} / \mathrm{C}(\mathrm{eq})_{\mathrm{L}}\right]$ as a function of temperature (Fig. 3), which is found to be linear as:

$$
y=-0.571 x+139.08
$$

\section{(Fig.3 here)}

Eq. (3) was then used to calculate the equilibrium concentration of dolomite dissolution in SW China when calculating the dolomite karst-related carbon sink with the MPD method.

\subsection{Calculation of runoff depth and evapotranspiration (ET)}

In MPD formula (Eq. 2), the runoff depth $(D)$ in the study area results from effective precipitation $\left(P_{e}\right)$, which is calculated as annual precipitation $(P)$ minus actual evapotranspiration (ET). The Penman-Monteith is a reliable and accurate accepted model based on metrological parameters, and has been applied to estimate reference 
evapotranspiration $\left(E T_{0}\right)$ under climate change. In this study, the daily $E T_{0}$ was calculated from a radiation corrective FAO56 Penman-Monteith model and the results were assumed to be equal to actual evapotranspiration $(E T)$ at each meteorological station in SW China. This can be expressed by the following equation (Allen et al., 1998):

$$
E T_{0}=\frac{0.408 \Delta\left(R_{n}-G\right)+\gamma \frac{900}{T+273} U_{2}\left(e_{s}-e_{a}\right)}{\Delta+\gamma\left(1+0.34 U_{2}\right)}
$$

where $E T_{0}$ is the reference evapotranspiration $\left(\mathrm{mm} \mathrm{d}^{-1}\right) ; R_{n}$ is the net radiation at the crop surface $\left(\mathrm{MJ} \mathrm{m}^{-2} \mathrm{~d}^{-1}\right) ; G$ is the soil heat flux density $\left(\mathrm{MJ} \mathrm{m}^{-2} \mathrm{~d}^{-1}\right.$ ) (at daily scale it is negligible, $\left.G_{d a y}=0\right) ; T$ is the mean daily air temperature at a height of $2 \mathrm{~m}\left({ }^{\circ} \mathrm{C}\right) ; U_{2}$ is the wind speed at a

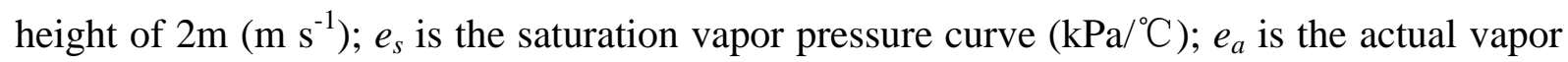
pressure; $\Delta$ is the slope vapor pressure curve $\left(\mathrm{kPa} /{ }^{\circ} \mathrm{C}\right)$, and $r$ is the psychometric constant $\left(\mathrm{kPa} /{ }^{\circ} \mathrm{C}\right)$. In order to obtain the reference evapotranspiration more accurately in the study area, a radiation calibration in China by Yin et al. (2008) was adopted.

\subsection{Soil pCO $\mathrm{Calculation}_{2}$}

Soil $\mathrm{CO}_{2}$ is a key driving force of karst processes and related carbon sequestration (Yang et al., 2012; Zeng et al., 2016), because the soil $\mathrm{CO}_{2}$ concentration is about 10 to 100 times higher than that in the atmosphere (Drever, 1994). Also, the $\mathrm{CO}_{2}$ partial pressure $\left(p \mathrm{CO}_{2}\right)$ in groundwater is mainly determined by the soil $p \mathrm{CO}_{2}$. Thus, $p \mathrm{CO}_{2}$ in groundwater can be supposed to be equilibrated with an actual soil $\mathrm{pCO}_{2}$ in this study, and calculated from Brook's (1983) formula in the MPD:

$$
\log \left(p \mathrm{CO}_{2}\right)=-3.74+2.09\left(1-\mathrm{e}^{-0.00172 \mathrm{AET}}\right)
$$

where $p \mathrm{CO}_{2}$ is the partial pressure of $\mathrm{CO}_{2}$ (atm) in soil, AET is the annual actual evapotranspiration (ET) during the growing period (mm/a). In this study, AET was assumed to 
be equal to the $E T_{0}$ calculated from the section 3.4.

\subsection{Spatial and temporal analysis of CSFs and TCS}

In order to reveal the spatial distribution of CSFs in SW China, the annual precipitation, evapotranspiration, equilibrium bicarbonate concentration across the SW China were determined by ordinary Kriging interpolation in ArcGIS 9.3. In this Study, the CSFs and TCS of SW China were calculated from $1 \mathrm{~km} \times 1 \mathrm{~km}$ grids through GIS spatial analysis.

Decadal averages were used to calculate and map the CSFs changes from 1970 to 2013. For example, the 1970 s represents the period of 1970 to 1979 , the 1980 s for $1980-1989$, the 1990s for 1990-1999, the 2000s for 2000-2009, but the 2010s only for four years from 2010 to 2013. The response and trend of each factor to changed climate conditions were obtained by linear regression analysis.

\section{Results}

\subsection{Spatial - temporal changes in climate in SW China}

Fig. 4 shows the changes in annual mean temperature, net total radiation, wind speed, precipitation and evapotranspiration $(E T)$ for the period of 1970-2013 from 240 meteorological stations in SW China (Fig. 1). An increasing trend of temperature was observed by the linear regression model during the study period, with a slope of $0.025^{\circ} \mathrm{C} / \mathrm{a}$ (Fig. 4). Precipitation showed a significant decreasing trend with slopes of $-1.7 \mathrm{~mm} / \mathrm{a}$ in the study period (Fig. 4). Although ET, net total radiation and wind speed demonstrated increasing trends from 2003 to 2013, the significant decreasing trends of these indexes were observed during the whole study period, with slopes of $-0.2 \mathrm{~mm} / \mathrm{a},-2.8 \mathrm{MJ} \mathrm{Day}^{-1} \mathrm{~m}^{-2} \mathrm{a}^{-1}$ and 
$-0.0068 \mathrm{~m} \mathrm{~s}^{-1} \mathrm{a}^{-1}$, respectively (Fig. 4). Furthermore, precipitation fluctuated more than ET: the highest precipitation value $(1,345 \mathrm{~mm})$ occurred in 2002 and the lowest in 2011 (963 mm), while the highest ET occurred in $2013(837 \mathrm{~mm})$ and the lowest $(716 \mathrm{~mm})$ in 1993.

\section{(Fig. 4 here)}

Fig. 5 shows the spatial changes and temporal trends of mean temperature and precipitation in SW China from 1970s to 2010s. The mean value of temperature and precipitation in SW China were $15.4^{\circ} \mathrm{C}$ and $1,147 \mathrm{~mm} / \mathrm{a}$, respectively. During the whole study period, the provinces with the largest increasing trends of temperature were Sichuan and Yunnan $\left(0.22\right.$ and $0.26^{\circ} \mathrm{C} /$ decade, respectively), as shown in Fig 5(c). However, Yunnan and Guizhou provinces showed the largest decrease in precipitation (Fig.5(c)), with -24.1 $\mathrm{mm} /$ decade and $-37.4 \mathrm{~mm} /$ decade, respectively. Most provinces demonstrated decrease in precipitation, with the exception of Sichuan, which increased a little $(+0.65 \mathrm{~mm} / \mathrm{decade})$ from the 1970s to 2010s (Fig.5(c)).

\section{(Fig. 5 here)}

\subsection{Spatial - temporal distribution of runoff depth}

As shown in Fig. 6, the annual $D$ varied from $200 \mathrm{~mm}$ to $1,200 \mathrm{~mm}$ with an average of $386 \mathrm{~mm}$. Distribution of annual $D$ values demonstrated a strong spatial gradient, with higher values in the southeast (Guangxi, Hunan) and lower values in the western part of the study area (Sichuan, Yunnan). Meanwhile, the annual $D$ values in the 2010 s were significantly lower than other periods, with the lowest values found in Yunnan and Guizhou provinces. 


\section{(Fig. 6 here)}

Table 2 shows the mean values of climate parameters and runoff depth $(D)$ in different time periods in the SW China karst region. It is noteworthy that precipitation and ET reached extreme values in 1990s, as much as $1,188 \mathrm{~mm}$ and as low as $754 \mathrm{~mm}$ (Table 2), respectively. The mean annual $D$ in the karst region showed an overall decreasing trend (about $18 \%$ decrease), with an anomaly in the 1990's when the highest D occurred (444 mm/a); the lowest $\mathrm{D}(308 \mathrm{~mm} / \mathrm{a})$ in $2010 \mathrm{~s}$.

\section{(Table 2 here)}

\subsection{Spatial - temporal distribution of equilibrium $\mathrm{HCO}_{3}{ }^{-}$concentration}

Equilibrium concentrations of the $\mathrm{HCO}_{3}{ }^{-}$in the karst region with different types of carbonate rocks were calculated by using MPD and Eq. (3) (modified MPD). The average $\left[\mathrm{HCO}_{3}{ }^{-}\right]_{\mathrm{eq}}$ values of limestone and dolomite were used to present the equilibrium concentration of mixed limestone/dolomite and impure carbonate under different conditions of temperature and $p \mathrm{CO}_{2}$. The mean temperature and soil $p \mathrm{CO}_{2}$ are significant controlling factors of $\left[\mathrm{HCO}_{3}{ }^{-}\right]_{\mathrm{eq}}$ in the modified MPD. The annual mean soil $p \mathrm{CO}_{2}$ was calculated by the Brook's formula (Brook et al., 1983). The decade mean values of soil $p \mathrm{CO}_{2}$ varied from 11,290 ppmv to 12,520 ppmv (Table 2). The equilibrium concentrations of bicarbonate based on temperature and soil $p \mathrm{CO}_{2}$ are shown in Fig. 7.

(Fig. 7 here) 
The mean $\left[\mathrm{HCO}_{3}{ }^{-}\right]_{\text {eq }}$ value is $4.29 \mathrm{mmol} / \mathrm{L}$ in the karst region of SW China, of which the highest and lowest values were observed in the western and eastern parts, respectively. The $\left[\mathrm{HCO}_{3}{ }^{-}\right]_{\mathrm{eq}}$ in the western portion of the karst region increased only slightly with climate change. In the central region, however, there was a remarkable change of $\left[\mathrm{HCO}_{3}{ }^{-}\right]_{\mathrm{eq}}$, decreasing from 1970 s to 1990 s and increasing after 2000 s. The $\left[\mathrm{HCO}_{3}{ }^{-}\right]_{\mathrm{eq}}$ concentrations for each type of carbonate in the study periods are shown in Table 2, with 4.01, 5.01, 4.58, and $4.63(\mathrm{mmol} / \mathrm{L})$ for limestone, dolomite, mixed limestone/dolomite and impure carbonate, respectively. These average equilibrium concentrations for different types of carbonates changed only slightly $(<5 \%)$ over the study periods despite the changing climate conditions. In all types of carbonates, the highest and lowest $\left[\mathrm{HCO}_{3}{ }^{-}\right]_{\mathrm{eq}}$ occurred in $1970 \mathrm{~s}(5.12 \mathrm{mmol} / \mathrm{L}$ for dolomite) and 1990s (3.92 mmol/L for limestone), respectively.

\subsection{Spatial-temporal distribution of CSFs}

Based on the modified MPD formula and GIS spatial calculation, the annual mean total carbon sink (TCS) of the SW China karst region was obtained, which was $68.9 \times 10^{5} \mathrm{t}$ C. Guangxi, Guizhou, Hunan, Yunnan, Hubei, Sichuan and Chongqing contributed $22.86 \%$, $22.61 \%, 20.46 \%, 11.78 \%, 8.5 \%, 8.29 \%$, and $5.52 \%$ to the total TCS in the study area, respectively. Distribution of annual CSFs also demonstrated the same strong spatial gradient as runoff depth $(D)$, with higher CSFs values in the east and lower values in the west (Fig. 8). The CSFs in central of Sichuan, northeast of Guangxi, east of Hunan were particularly high (Fig. 8). In 1990s, the CSFs in Guangxi, Hunan, Guizhou were the highest. In 2010s, however, there was a remarkable decrease in the CSFs in Sichuan and Guizhou provinces, as shown in 
Fig. 8. The effect of climate change on TCS is that there was, overall, a $19 \%$ decrease in the entire karst region of SW China from 1970s to 2010s.

(Fig. 8 here)

\section{Discussion}

\subsection{Comparison with other methods}

MPD is a theoretical calculation of optimized carbonate dissolution assuming a steady rate of change. It corresponds, physically, to the theoretical carbonate rock layer dissolved by karstic processes in the basin catchment area. It is necessary to check for similarity between the MPD-based results and those by other methods of calculating carbonate dissolution rates. As shown in Table 3, the calculated karst-related carbon sink fluxes (CSFs) in SW China, based on the modified MPD formula, ranged from 7.4 to $10.4 \mathrm{t} \mathrm{C} \mathrm{km}^{-2} \mathrm{a}^{-1}$ (or 27.1 to $38.1 \mathrm{t}$ $\mathrm{CO}_{2} \mathrm{~km}^{-2} \mathrm{a}^{-1}$ ) from 1970 s to $2010 \mathrm{~s}$, and the average CSFs in SW China was $9.36 \mathrm{t} \mathrm{C} \mathrm{km}^{-2} \mathrm{a}^{-1}$. To assess the results of the MPD method, we compared the modified MPD-based results with those by other methods (Table 4). Results show that the CSFs are mostly within 5\% of each other, with only one exception still being within $20 \%$. For example, the CSFs in upper reaches of Xijiang River (tributary catchments of the Pearl River) was $27.05 \mathrm{t} \mathrm{CO}_{2} \mathrm{~km}^{-2} \mathrm{a}^{-1}$, based on the solute load method by $\mathrm{Xu}$ and Liu et al (2007), while the CSFs obtained from the modified MPD was $27.75 \mathrm{t} \mathrm{CO}_{2} \mathrm{~km}^{-2} \mathrm{a}^{-1}$. A high-resolution (15 min interval), monitoring-based CSFs estimation of the three catchments in Guizhou ranged from 28.84 to $39.13 \mathrm{t} \mathrm{CO}_{2} \mathrm{~km}^{-2} \mathrm{a}^{-1}$ during the period of 2007 to 2013 (Zeng et al., 2016), while the CSFs obtained from the modified MPD ranged from 33.90 to $38.62 \mathrm{t} \mathrm{CO}_{2} \mathrm{~km}^{-2} \mathrm{a}^{-1}$ in these three 
catchments from 2007 to 2013.

\section{(Tables 3 and 4 here)}

In addition, Han and Liu (2004) measured the water chemistry in numerous tributary catchments of the Yangtze River in Guizhou province and the CSFs of these catchments was $38.75 \mathrm{t} \mathrm{CO}_{2} \mathrm{~km}^{-2} \mathrm{a}^{-1}$, which is close to our calculation (40.15 $\mathrm{t} \mathrm{CO}_{2} \mathrm{~km}^{-2} \mathrm{a}^{-1}$ ). The karst-related carbon sink flux in the Pearl River Basin in SW China was about $42.70 \mathrm{t} \mathrm{CO}_{2} \mathrm{~km}^{-2} \mathrm{a}^{-1}$ by Cao et al (2011) who used a regression equation containing major impact factors of karst processes (solution ratio of standard limestone tablets, precipitation, soil respiration and NPP), which is also close to our MPD-based result (45.32 $\left.\mathrm{t} \mathrm{CO}_{2} \mathrm{~km}^{-2} \mathrm{a}^{-1}\right)$.

All these comparisons show that the modified MPD method is as effective as other methods in calculating the karst-related carbon sink fluxes. This also indicates that maximum potential carbonate dissolution has been maintained in nature due to the fast dissolution kinetics of carbonate rocks (Dreybrodt, 1988; Gombert, 2002; Liu et al., 2010; Liu et al., 2011)

5.2. Runoff depth: the major factor determining the carbonate weathering-related carbon sink

The relationships between carbon sink flux (CSFs) and precipitation, temperature, runoff depth $(D)$, or $\left[\mathrm{HCO}_{3}{ }^{-}\right]_{\mathrm{eq}}$ of the whole karst region in SW China from 1970s to 2010s are shown in Fig. 9. There is a strong positive relationship between CSFs and $D$ or precipitation, but no significant relationship between CSFs and mean temperature or $\left[\mathrm{HCO}_{3}^{-}\right]_{\mathrm{eq}}$. This suggests that the variation in CSFs is mainly controlled by precipitation or $D$ during the study period, and the influence of temperature and $\left[\mathrm{HCO}_{3}{ }^{-}\right]_{\mathrm{eq}}$ on CSFs variations can be ignored. 
Furthermore, a comparison is provided in Table 3 and Fig. 10 for the seven provinces in SW China in the study period. It can be seen that, in the whole study period, the largest decrease in CSFs occurred in Guizhou (-37\%) and Yunnan (-32\%). During the same time period, these two provinces experienced a similar decrease in $D(190 \mathrm{~mm}$ and $90 \mathrm{~mm}$ decrease in the past 40 years, respectively) and precipitation $(156 \mathrm{~mm}$ and $106 \mathrm{~mm}$ in the past 40 years, respectively). However, there was an increase in air temperature $\left(0.33\right.$ and $1.04{ }^{\circ} \mathrm{C}$ increase over the past 40 years, respectively) and $\left[\mathrm{HCO}_{3}{ }^{-}\right]_{\mathrm{eq}}$ in the karst regions of Guizhou and Yunnan. Fig. 10 also demonstrates that the trends of decreasing TCS and CSFs among the provinces were similar. More important is that a synchronous trend was found between CSFs and $D$, but a reversed trend was observed between CSFs and $\left[\mathrm{HCO}_{3}{ }^{-}\right]_{\mathrm{eq}}$ (Fig. 10), indicating that runoff depth was the major factor determining the karst-related carbon sink.

\section{(Figs. 9 and 10 here)}

According to multiple linear regression analysis, the karst-related carbon sink fluxes can be approximated by the following equation:

$$
\mathrm{CSFs}=10.423+0.021 \mathrm{D}-2.184\left[\mathrm{HCO}_{3}{ }^{-}\right]_{\mathrm{eq}}, \mathrm{R}^{2}=0.987, \mathrm{p}<0.01 \quad(6) \text {, }
$$

where CSFs is the karst-related carbon sink, D is the runoff depth $(\mathrm{mm} / \mathrm{a})$, and $\left[\mathrm{HCO}_{3}{ }^{-}\right]_{\mathrm{eq}}$ $(\mathrm{mmol} / \mathrm{L})$ is the equilibrium bicarbonate concentration under local climate conditions.

The strong positive correlation between CSFs and $D$ but not $\left[\mathrm{HCO}_{3}{ }^{-}\right]$found in $\mathrm{SW}$ China was consistent with field observations (Godsey et al., 2009; Clow and Mast, 2010; Zeng et al., 2016), in which the chemostatic behavior of $\left[\mathrm{HCO}_{3}{ }^{-}\right]$was found. The chemostatic behavior in catchments means that concentration of weathering products in streams often show relatively little variation compared to changes in discharge, both at storm and interannual timescales (Godsey et al., 2009; Clow \& Mast, 2010). The mechanisms for the chemostatic behavior of 
$\left[\mathrm{HCO}_{3}{ }^{-}\right]$in karst catchments may include two controls (Zeng et al., 2016). One is that the decrease in $\left[\mathrm{HCO}_{3}{ }^{-}\right]$is caused by simple dilution is counterbalanced by an increase in $\left[\mathrm{HCO}_{3}{ }^{-}\right]$ induced by a soil $\mathrm{CO}_{2}$ effect (Liu et al., 2007) in the rainy periods. The second is the fast kinetics of carbonate dissolution, which overcomes the dilution effect by the discharge increase after a rainfall (the so-called transport-limited behavior, Maher, 2010). This is the reason why there were high similarities in variation patterns between CSFs and $D$ in all provinces from 1970s to 2010s (Fig. 10).

5.3. Comparison of carbon sink fluxes among the provinces: difference in climate and carbonate lithologies

According to Eq. (1) and Eq. (6), the carbon sink flux is determined by $D$ and $\left[\mathrm{HCO}_{3}{ }^{-}\right]_{\mathrm{eq}}$. Therefore, as shown in Table 3, Hunan Province had the highest CSFs among the seven provinces due to its highest $D(666 \mathrm{~mm} / \mathrm{a})$ and a larger area of dolomite and mixed limestone/dolomite distribution (Fig. 2), with thus higher $\left[\mathrm{HCO}_{3}{ }^{-}\right]_{\mathrm{eq}}$ (Table 3).

Sichuan and Yunnan had higher $\left[\mathrm{HCO}_{3}{ }^{-}\right]_{\mathrm{eq}}$ (Table 3) among the seven provinces. However, their lowest $D(159 \mathrm{~mm} / \mathrm{a}$ and $181 \mathrm{~mm} / \mathrm{a}$, respectively $)$ contributed the lowest carbon sink fluxes in these two provinces. The main reason for the CSFs difference among provinces is the regional climate difference. Most of the area in Yunnan, Guizhou, and Sichuan are mountains and Plateaus (Tibet Plateau and Yunnan-Guizhou plateau), thus having higher average elevation, as illustrated in Fig. 1. The provinces in southeast of SW China, however, are mainly dominated by plains and are more strongly affected by the monsoonal climate. Therefore, the area of southeast thus has more rainfall than the northwest.

\subsection{Implication for the carbon cycle}


It has been shown that the CSF in SW China karst area is $9.36 \mathrm{t} \mathrm{C} \mathrm{km}^{-2} \mathrm{a}^{-1}$ (or $34.3 \mathrm{t} \mathrm{CO}_{2}$ $\mathrm{km}^{-2} \mathrm{a}^{-1}$ ), which is about 18 times larger than that in a silicate-dominated terrain (about $1.94 \mathrm{t}$ $\mathrm{CO}_{2} \mathrm{~km}^{-2} \mathrm{a}^{-1}$, Jin et al., 2014). Moreover, the carbon sink produced by carbonate weathering was sensitive to climate change, due to the runoff effect determined by the transport-limited behavior of carbonate weathering (as evidenced by the chemostatic behavior of $\left[\mathrm{HCO}_{3}{ }^{-}\right]$ shown earlier). For example, the karst-related carbon sink showed a $19 \%$ decrease due to the decrease in runoff depth in SW China from 1970 to 2013. Therefore, this study suggests that there will be a rapid response of the karst-related carbon sink to future climate change, which needs to be considered in the modern global carbon cycle study. Huntington (2006) had shown the evidence for intensification of the global water cycle (2-5\% increase per degree) due to global warming, so there will be an increase in the karst-related carbon sink (Liu et al., 2010). Though Bond-Lamberty and Thomson (2010) showed that soil respiration rates have increased ( $0.1 \%$ in the past 20 years from 1989 to 2008$)$ because of climate warming, the dependence of $\mathrm{CSF}$ on $\left[\mathrm{HCO}_{3}{ }^{-}\right]$was minor due to much weaker increase in $\left[\mathrm{HCO}_{3}^{-}\right]$than runoff increase.

\section{Conclusion}

Based on the modified MPD formula and GIS, this study used daily climatic data from the 240 meteorological stations during 1970-2013 and distribution of various carbonate rocks in SW China to analyze perturbations of karst-related carbon sink under changed climate conditions. We focused on four aspects: (1) spatiotemporal variations of the main determinants controlling the carbon sink fluxes, (2) spatiotemporal variations of the total karst-related carbon sink (TCS) and carbon fluxes (CSFs), (3) climatic impacts on the CSFs 
variations, and (4) possible implications of this study.

It was found that the TCS in SW China experienced a dramatic change with regional climate, and there was a trend with TCS decreasing by about $19 \%$ from 1970 to 2013 . This decrease occurred mostly in Guizhou and Yunnan provinces, which experienced larger decreases in runoff depth $(190 \mathrm{~mm}$ and $90 \mathrm{~mm}$ in the past 40 years, respectively) due to increased air temperature $\left(0.33^{\circ} \mathrm{C}\right.$ and $1.04^{\circ} \mathrm{C}$ in the past 40 years, respectively) and decreased precipitation (156 $\mathrm{mm}$ and $106 \mathrm{~mm}$ in the past 40 years, respectively) in the karst region during the same period. The mean value of CSFs in SW China, calculated by the modified MPD method, was approximately $9.36 \mathrm{t} \mathrm{C} \mathrm{km}^{-2} \mathrm{a}^{-1}$. In addition, there were large differences in CSFs among the provinces, attributed to the difference in regional climate and carbonate lithologies. These spatiotemporal changes depended mainly on the hydrological variations (i.e., discharge or runoff depth) in the karst regions during climate changes over about 40 years. Thus, this study suggests that the karst-related carbon sink could respond to future climate change quickly, and needs to be considered in the modern global carbon cycle model.

\section{Acknowledgements}

This research was supported by the Ministry of Science and Technology of China (2016YFC0502306 and 2013CB956700) and the National Science Foundation of China (41430753, 41472321 and 41172331). Special thanks are given to Prof. G.L. Macpherson for her thoughtful academic and editorial suggestions on the manuscript. 


\section{References}

Allen, R.G., Pereira, L.S., Raes, D., Smith, M., 1998. Crop evapotranspiration: Guideline for computing crop water requirement. FAO Irrigation and Drainage Paper No.56, Food and Agriculture Organization, Italy.

Andrews, J. A., Schlesinger, W. H., 2001. Soil $\mathrm{CO}_{2}$ dynamics, acidification, and chemical weathering in a temperate forest with experimental $\mathrm{CO}_{2}$ enrichment. Global Biogeochemical Cycles 15, 149-162.

Berner, R.A., Lasaga, A.T., Garrels, R.M., 1983. The carbonate-silicate geochemical cycle and its effect on atmospheric carbon dioxide over the past 100 million years. American Journal of Science 283, 641-683.

Berner, R.A., 1992. Weathering, plants, and the long-term carbon cycle. Geochimica et Cosmochimica Acta 56, 3225-3231.

Bond-Lamberty, B., Thomson, A., 2010. Temperature-associated increases in the global soil respiration record. Nature 464, 579-582.

Brook, G.A., Folkoff, M.E., Box, E.O., 1983. A world model of soil carbon dioxide. Earth Surface Processes and Landforms 8, 79-88.

Cao, J.H., Yang, H., Kang, Z.Q., 2011. Preliminary regional estimation of carbon sink flux by carbonate rock corrosion: A case study of the Pearl River Basin. Chinese Science Bulletin $56,3766-3773$.

Clow, D.W., Mast, M. A., 2010. Mechanisms for chemostatic behavior in catchments: 
Implications for $\mathrm{CO}_{2}$ consumption by mineral weathering. Chemical Geology 269, 40-51.

Drever, J.I., 1994. The effect of land plants on weathering rates of silicate minerals. Geochimica et Cosmochimica Acta 58, 2325-2332.

Dreybrodt, W., 1988. Processes in karst systems. Springer Series in Physical Environment, Springer, Heidelberg.

Friedlingstein, P., Cox, P., Betts, R., 2006. Climate-carbon cycle feedback analysis: Results from the (CMIP)-M-4 model intercomparison. Journal of Climate 14, 3337-3353.

Gedney, N., Cox, P.M., Betts, R.A., 2006. Detection of a direct carbon dioxide effect in continental river runoff records. Nature 439, 835-838

Gislason, S.R., Oelkers, E.H., Eiriksdottir, E.S., 2009. Direct evidence of the feedback between climate and weathering. Earth and Planetary Science Letters 277, 213-222.

Godsey, S.E., Kirchner, J.W., Clow, D.W., 2009. Concentration-discharge relationships reflect chemostatic characteristics of US catchments. Hydrological Processes 23, 1844-1864.

Gombert, P., 2002. Role of karstic dissolution in global carbon cycle. Global and Planetary Change 33, 177-184.

Han, G., Liu, C., 2004. Water geochemistry controlled by carbonate dissolution: a study of the river waters draining karst-dominated terrain, Guizhou Province, China. Chemical Geology 204, 1-21.

Huntington, T. G., 2006. Evidence for intensification of the global water cycle: Review and synthesis. Journal of Hydrology 319, 83-95.

Jin, L., Ogrinc, N., Yesavage, T., Hasenmueller, E.A., Ma, L., Sullivan, P.L., Kaye, J., Duffy, C., Brantley, S.L., 2014. The $\mathrm{CO}_{2}$ consumption potential during gray shale weathering: Insights from the evolution of carbon isotopes in the Susquehanna Shale Hills critical zone observatory. Geochimica et Cosmochimica Acta 142, 260-280.

Liu, Z., Zhao, J., 2000. Contribution of carbonate rock weathering to the atmospheric $\mathrm{CO}_{2}$ 
sink. Environmental Geology 39, 1053-1058.

Liu, Z., Li, Q., Wang, J., 2007. Seasonal, diurnal and storm-scale hydrochemical variations of typical epikarst springs in subtropical karst areas of $\mathrm{SW}$ China: soil $\mathrm{CO}_{2}$ and dilution effects. Journal of Hydrology 337, 207-223.

Liu, Z., Dreybrodt, W., Wang, H., 2010. A new direction in effective accounting for the atmospheric $\mathrm{CO}_{2}$ budget: considering the combined action of carbonate dissolution, the global water cycle and photosynthetic uptake of DIC by aquatic organisms. Earth Science Reviews 99, 162-172.

Liu, Z., Dreybrodt, W., Liu, H., 2011. Atmospheric $\mathrm{CO}_{2}$ sink: silicate weathering or carbonate weathering? Applied Geochemistry 26s: 292-294.

Liu, Z., Dreybrodt, W., 2015. Significance of the carbon sink produced by $\mathrm{H}_{2} \mathrm{O}-$ carbonate- $\mathrm{CO}_{2}$-aquatic phototroph. Science Bulletin 60, 182-191.

Macpherson, G.L., Roberts, J.A., Blair, J.M., Townsend, M.A., Fowle, D.A., Beisner, K.R., 2008. Increasing shallow groundwater $\mathrm{CO}_{2}$ and limestone weathering, Konza Prairie, USA. Geochimica et Cosmochimica Acta 72, 5581-5599.

Maher, K., 2010. The dependence of chemical weathering rates on fluid residence time. Earth and Planetary Science Letters 294, 101-110.

Melnikov, N., O’Neill, B., 2006. Learning about the carbon cycle from global budget data. Geophysical Research Letters 33, L02705.

Raymond, P.A. and Cole, J.J., 2003. Increase in the Export of Alkalinity from North America’s Largest River. Science 301, 88-91.

Raymond, P.A., Oh, N.H., Turner, R.E., Broussard, W., 2008. Anthropogenically enhanced fluxes of water and carbon from the Mississippi River. Nature 451, 449-452.

Sabine, C.L., et al., 2004. Current status and past trends of the carbon cycle. In: Field CB, Raupach MR (eds) The global carbon cycle: integrating humans, climate, and the natural 
world. Island Press, Washington, pp 17-44.

Tans, P.P., Fung, I.Y., Takahashi, T., 1990. Observational constraints on the global atmospheric $\mathrm{CO}_{2}$ budget. Science 247, 1431-1438.

Xu, Z., Liu, C., 2007. Chemical weathering in the upper reaches of Xijiang River draining the Yunnan-Guizhou Plateau, Southwest China. Chemical Geology 239, 83-95.

Yang, R., Liu, Z., Zeng, C., Zhao, M., 2012. Response of epikarst hydrochemical changes to soil $\mathrm{CO}_{2}$ and weather conditions at Chenqi, Puding, SW China. Journal of Hydrology $468-469,151-158$.

Yin, Y., Wu, S., Zheng, D., 2008. Radiation calibration of FAO56 Penman-Monteith model to estimate reference crop evapotranspiration in China. Agricultural Water Management 95, $77-84$.

Yuan, D., 1997. The carbon cycle in karst. Zeitschrift fur Geomorphologie, NF 108, 91-102.

Zeng, C., Liu, Z., Zhao, M., Yang, R., 2016. Hydrologically-driven variations in the karst-related carbon sink fluxes: insights from high-resolution monitoring of three karst catchments in Southwest China. Journal of Hydrology 533, 74-90. 


\section{Table 1}

Karstic areas of the seven provinces in SW China.

\begin{tabular}{ccccccccc}
\hline Province & Yunnan & Guizhou & Sichuan & Guangxi & Huanan & Hubei & Chongqing & Total \\
\hline Karstic & & & & & & & & \\
area & 19.1 & 14.5 & 14.0 & 10.3 & 8.2 & 5.9 & 3.2 & 75.2 \\
$\left(10^{4} \cdot \mathrm{km}^{2}\right)$ & & & & & & & \\
\hline
\end{tabular}




\section{Table 2}

Decade mean values of temperature $\left(T_{\text {mean }}\right)$, precipitation $(P)$, evapotranspiration $(E T)$, runoff depth $(D)$, soil $\mathrm{CO}_{2}$ and equilibrium $\mathrm{HCO}_{3}{ }^{-}$concentrations of limestone $\left[(\mathrm{Ceq})_{\mathrm{L}}\right]$, dolomite $\left[(\mathrm{Ceq})_{\mathrm{D}}\right]$, mixed limestone/dolomite $\left[(\mathrm{Ceq})_{\mathrm{L} / \mathrm{D}}\right]$, and impure carbonate $\left[(\mathrm{Ceq})_{\mathrm{I}}\right]$ in the $\mathrm{SW}$ China karst region from 1970s to 2010s.

\begin{tabular}{lccccccccc}
\hline Period & $\begin{array}{c}T_{\text {mean }} \\
\left({ }^{\circ} \mathrm{C}\right)\end{array}$ & $\begin{array}{c}E T \\
(\mathrm{~mm} / \mathrm{a})\end{array}$ & $\begin{array}{c}\mathrm{D} m / \mathrm{a}) \\
(\mathrm{mm} / \mathrm{a})\end{array}$ & $\begin{array}{c}p \mathrm{CO}_{2} \\
(\mathrm{ppmv})\end{array}$ & $\begin{array}{r}(\mathrm{Ceq})_{\mathrm{L}} \\
(\mathrm{mmol} / \mathrm{L})\end{array}$ & $\begin{array}{r}(\mathrm{Ceq})_{\mathrm{D}} \\
(\mathrm{mmol} / \mathrm{L})\end{array}$ & $\begin{array}{r}(\mathrm{Ceq})_{\mathrm{L} / \mathrm{D}} \\
(\mathrm{mmol} / \mathrm{L})\end{array}$ & $\begin{array}{r}(\mathrm{Ceq})_{\mathrm{I}} \\
(\mathrm{mmol} / \mathrm{L})\end{array}$ \\
\hline $1970 \mathrm{~s}$ & 15.28 & 1172 & 802 & 394 & 12481 & 4.09 & 5.12 & 4.65 & 4.75 \\
$1980 \mathrm{~s}$ & 15.35 & 1130 & 776 & 373 & 11852 & 4.01 & 5.01 & 4.57 & 4.63 \\
$1990 \mathrm{~s}$ & 15.60 & 1188 & 754 & 444 & 11290 & 3.92 & 4.90 & 4.47 & 4.54 \\
$2000 \mathrm{~s}$ & 15.96 & 1123 & 778 & 360 & 11889 & 3.95 & 4.94 & 4.50 & 4.58 \\
$2010 \mathrm{~s}$ & 15.95 & 1075 & 803 & 308 & 12520 & 4.01 & 5.06 & 4.57 & 4.65 \\
\hline
\end{tabular}




\section{Table 3}

Statistics on the temporal variations in mean temperature $\left(T_{\text {mean }}\right)$, runoff depth $(D)$, equilibrium $\mathrm{HCO}_{3}{ }^{-}$concentration $\left[\mathrm{HCO}_{3}{ }^{-}\right]_{\mathrm{eq}}$, carbon sink flux $(\mathrm{CSF} \mathrm{s})$, and total carbon sink (TCS) in the seven provinces of SW China from 1970s to 2010s.

\begin{tabular}{|c|c|c|c|c|c|c|c|c|c|}
\hline Decade & Items & Sichuan & Chongqing & Hubei & Yunnan & Guizhou & Hunan & Guangxi & SW China \\
\hline \multirow[t]{5}{*}{$1970 \mathrm{~s}$} & $T_{\text {mean }}\left({ }^{\circ} \mathrm{C}\right)$ & 10.21 & 16.00 & 15.62 & 15.29 & 15.36 & 16.99 & 20.23 & 15.28 \\
\hline & $D(\mathrm{~mm} / \mathrm{a})$ & 104 & 444 & 313 & 215 & 498 & 646 & 747 & 394 \\
\hline & {$\left[\mathrm{HCO}_{3}{ }^{-}\right]_{\mathrm{eq}}(\mathrm{mmol} / \mathrm{L})$} & 4.60 & 3.80 & 4.00 & 4.48 & 4.00 & 4.12 & 3.78 & 4.21 \\
\hline & $C S F \mathrm{~s}\left(\mathrm{t} \mathrm{C} \mathrm{km}^{-2} \mathrm{a}^{-1}\right)$ & 3.8 & 12.1 & 9.0 & 4.7 & 11.9 & 17.3 & 16.7 & 9.6 \\
\hline & $\operatorname{TCS}\left(10^{5} \mathrm{t} C\right)$ & 5.4 & 3.9 & 5.3 & 8.9 & 17.2 & 14.2 & 17.2 & 72.1 \\
\hline \multirow[t]{5}{*}{$1980 \mathrm{~s}$} & $T_{\text {mean }}\left({ }^{\circ} \mathrm{C}\right)$ & 10.23 & 15.79 & 15.43 & 15.46 & 15.45 & 17.04 & 20.42 & 15.35 \\
\hline & $D(\mathrm{~mm} / \mathrm{a})$ & 184 & 538 & 556 & 181 & 428 & 616 & 532 & 374 \\
\hline & {$\left[\mathrm{HCO}_{3}{ }^{-}\right]_{\mathrm{eq}}(\mathrm{mmol} / \mathrm{L})$} & 4.75 & 3.87 & 4.00 & 4.59 & 4.07 & 4.22 & 3.88 & 4.30 \\
\hline & $C S F \mathrm{~s}\left(\mathrm{t} \mathrm{C} \mathrm{km} \mathrm{ka}^{-1}\right)$ & 4.7 & 13.5 & 12.4 & 4.3 & 10.2 & 15.9 & 12.6 & 8.9 \\
\hline & $\operatorname{TCS}\left(10^{5} \mathrm{t} C\right)$ & 6.6 & 4.3 & 7.3 & 8.2 & 14.7 & 13.1 & 12.9 & 67.1 \\
\hline \multirow[t]{5}{*}{$1990 \mathrm{~s}$} & $T_{\text {mean }}\left({ }^{\circ} \mathrm{C}\right)$ & 10.58 & 16.10 & 15.88 & 15.72 & 15.58 & 17.30 & 20.60 & 15.60 \\
\hline & $D(\mathrm{~mm} / \mathrm{a})$ & 176 & 490 & 467 & 229 & 520 & 780 & 767 & 444 \\
\hline & {$\left[\mathrm{HCO}_{3}{ }^{-}\right]_{\mathrm{eq}}(\mathrm{mmol} / \mathrm{L})$} & 4.64 & 3.86 & 4.00 & 4.47 & 4.00 & 4.12 & 3.78 & 4.21 \\
\hline & $C S F \mathrm{~s}\left(\mathrm{t} \mathrm{C} \mathrm{km}^{-2} \mathrm{a}^{-1}\right)$ & 4.5 & 12.1 & 10.3 & 5.4 & 12.1 & 19.7 & 17.7 & 10.4 \\
\hline & $\operatorname{TCS}\left(10^{5} \mathrm{t} \mathrm{C}\right)$ & 6.3 & 3.9 & 6.1 & 10.2 & 17.6 & 16.2 & 18.2 & 78.5 \\
\hline \multirow[t]{3}{*}{$2000 \mathrm{~s}$} & $T_{\text {mean }}\left({ }^{\circ} \mathrm{C}\right)$ & 11.02 & 16.62 & 16.22 & 16.04 & 15.85 & 17.69 & 20.91 & 15.96 \\
\hline & $D(\mathrm{~mm} / \mathrm{a})$ & 172 & 453 & 426 & 172 & 430 & 629 & 589 & 360 \\
\hline & {$\left[\mathrm{HCO}_{3}{ }^{-}\right]_{\mathrm{eq}}(\mathrm{mmol} / \mathrm{L})$} & 4.64 & 3.89 & 4.04 & 4.52 & 4.02 & 4.17 & 3.85 & 4.25 \\
\hline
\end{tabular}




\begin{tabular}{|c|c|c|c|c|c|c|c|c|c|}
\hline & $C S F \mathrm{~s}\left(\mathrm{t} \mathrm{C} \mathrm{km} \mathrm{km}^{-2}\right)$ & 3.7 & 11.4 & 9.6 & 4.0 & 10.1 & 16.1 & 13.9 & 8.5 \\
\hline & $\operatorname{TCS}\left(10^{5} \mathrm{t} \mathrm{C}\right)$ & 5.2 & 3.7 & 5.7 & 7.8 & 14.6 & 13.2 & 14.3 & 64.5 \\
\hline \multirow[t]{5}{*}{$2010 \mathrm{~s}$} & $T_{\text {mean }}\left({ }^{\circ} \mathrm{C}\right)$ & 11.13 & 16.53 & 16.04 & 16.33 & 15.69 & 17.55 & 20.67 & 15.95 \\
\hline & $D(\mathrm{~mm} / \mathrm{a})$ & 156 & 373 & 343 & 106 & 259 & 601 & 596 & 308 \\
\hline & {$\left[\mathrm{HCO}_{3}^{-}\right]_{\mathrm{eq}}(\mathrm{mmol} / \mathrm{L})$} & 4.70 & 4.02 & 4.13 & 4.60 & 4.11 & 4.26 & 3.84 & 4.32 \\
\hline & $C S F \mathrm{~s}\left(\mathrm{t} \mathrm{C} \mathrm{km} \mathrm{a}^{-2}\right)$ & 4.0 & 9.8 & 7.8 & 2.5 & 7.1 & 15.7 & 14.0 & 7.4 \\
\hline & $\operatorname{TCS}\left(10^{5} \mathrm{t} C\right)$ & 5.6 & 3.1 & 4.6 & 4.7 & 10.2 & 12.9 & 14.4 & 55.5 \\
\hline
\end{tabular}

\section{Table 4}

Comparison of the karst-related carbon sink fluxes $\left(\mathrm{t} \mathrm{CO}_{2} \mathrm{~km}^{-2} \mathrm{a}^{-1}\right)$ between the MPD-based results and those by other methods.

\begin{tabular}{lrrrrr}
\hline Site & Upper Xijiang R. & Guizhou 1 & Guizhou 2 & Yangtze R. & Pearl R. \\
\hline Other studies & $27.05^{\mathrm{a}}$ & $28.84^{\mathrm{b}}$ & $39.13^{\mathrm{b}}$ & $38.75^{\mathrm{c}}$ & $42.7^{\mathrm{d}}$ \\
This study & 27.75 & 33.9 & 38.62 & 40.15 & 45.32 \\
Ratio, this to other & 1.03 & 1.18 & 0.99 & 1.04 & 1.06
\end{tabular}

${ }^{\mathrm{a}} \mathrm{Xu}$ and Liu et al., 2007; ${ }^{\mathrm{b}}$ Zeng et al., 2016; ${ }^{\mathrm{c}} \mathrm{Han}$ and Liu, 2004; ${ }^{\mathrm{d}}$ Cao et al., 2011. 


\section{Figure captions}

Fig. 1. Location of SW China and the distribution of meteorological stations in the area (modified after http://cdc.cma.gov.cn).

Fig. 2. Distribution of various carbonate rocks in SW China (modified after the Institute of Karst Geology, Chinese Academy of Geological Sciences, 1985).

Fig. 3. Correlation between $(\mathrm{Ceq})_{\mathrm{D}} /(\mathrm{Ceq})_{\mathrm{L}}$ and temperature. $(\mathrm{Ceq})_{\mathrm{D}}$ and $(\mathrm{Ceq})_{\mathrm{L}}$ are equilibrium concentrations of bicarbonate for dolomite and limestone, respectively.

Fig. 4. Annual mean value and trends of temperature $\left(T_{\text {mean }}\right)$, net total radiation $\left(R_{\mathrm{n}}\right)$, wind speed (WS), precipitation $(P)$ and evapotranspiration $(E T)$ of the 240 meteorological stations in and around SW China from 1970 to 2013 (dotted line: data missing).

Fig. 5. Spatial distribution and temporal trends of mean temperature and precipitation in SW China from 1970s to 2010s.

Fig. 6. Spatial distribution of runoff depth $(D)$ in SW China from 1970s to 2010s.

Fig. 7. Spatial distribution of equilibrium $\mathrm{HCO}_{3}{ }^{-}$concentration $\left[\mathrm{HCO}_{3}{ }^{-}\right]_{\mathrm{eq}}$ in $\mathrm{SW}$ China karst 
area from 1970s to 2010s.

Fig. 8. Spatial distribution of the karst-related carbon sink fluxes (CSFs) in SW China from 1970s to 2010s.

Fig. 9. Relationship between carbon sink flux (CSFs) and precipitation, mean temperature, runoff depth $(D)$, or $\left[\mathrm{HCO}_{3}{ }^{-}\right]_{\mathrm{eq}}$ of the seven provinces in SW China from 1970s to 2010s.

Fig. 10. Variations in total carbon sink (TCS), carbon sink flux (CSFs), runoff depth $(D)$ and equilibrium $\mathrm{HCO}_{3}{ }^{-}$concentration $\left[\mathrm{HCO}_{3}{ }^{-}\right]_{\mathrm{eq}}$ in the seven provinces and entire SW China karst area from 1970s to 2010s. 


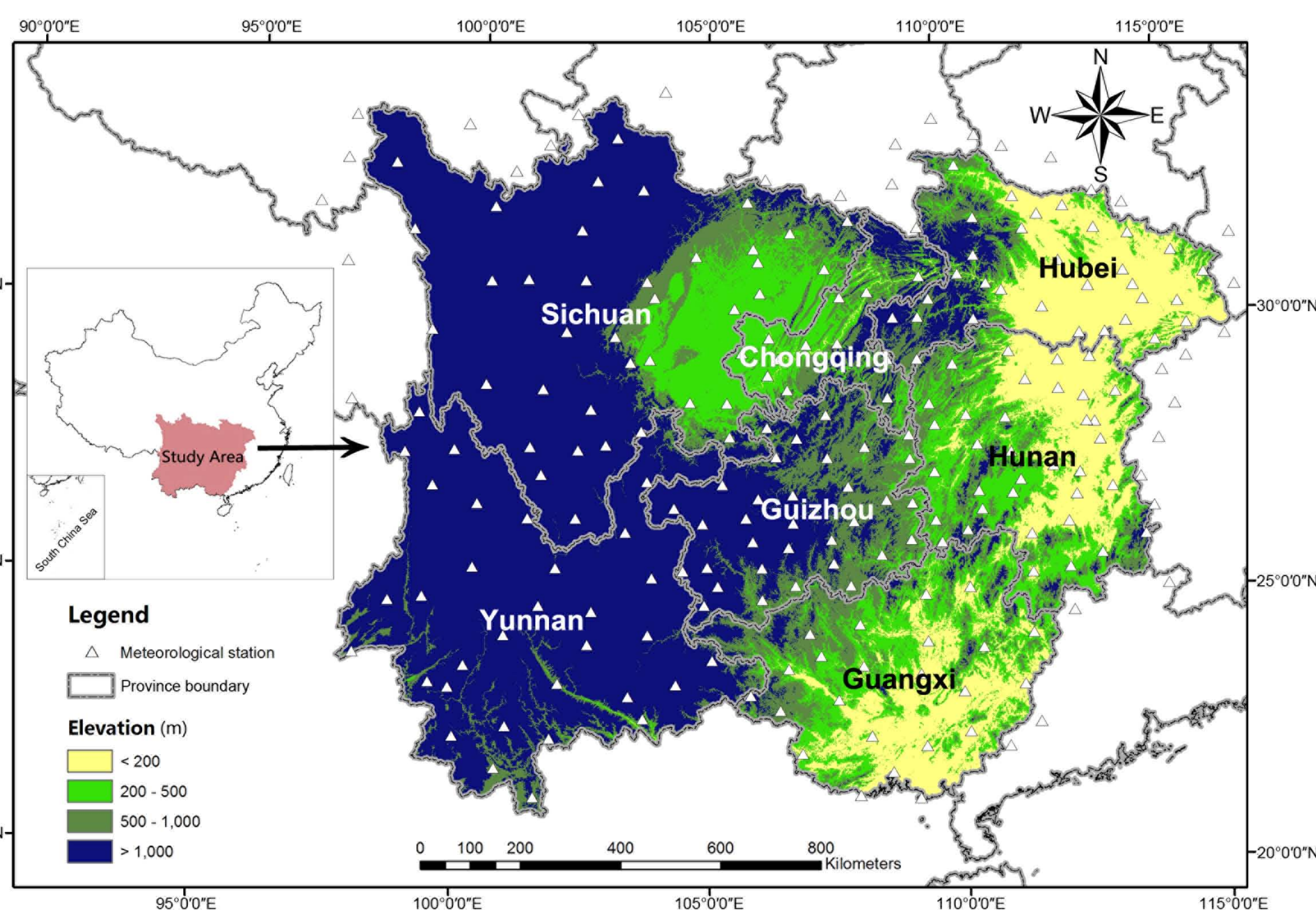




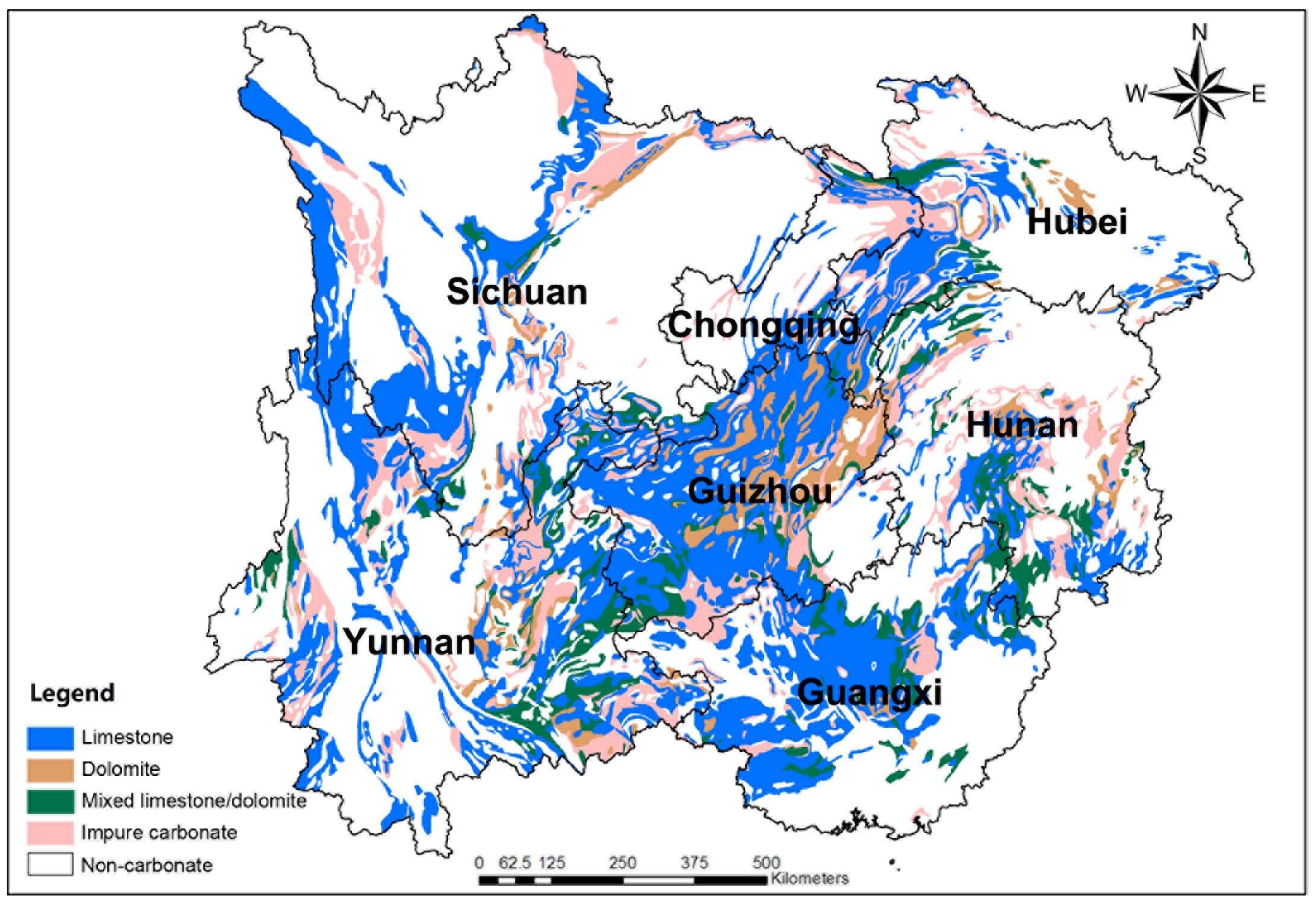




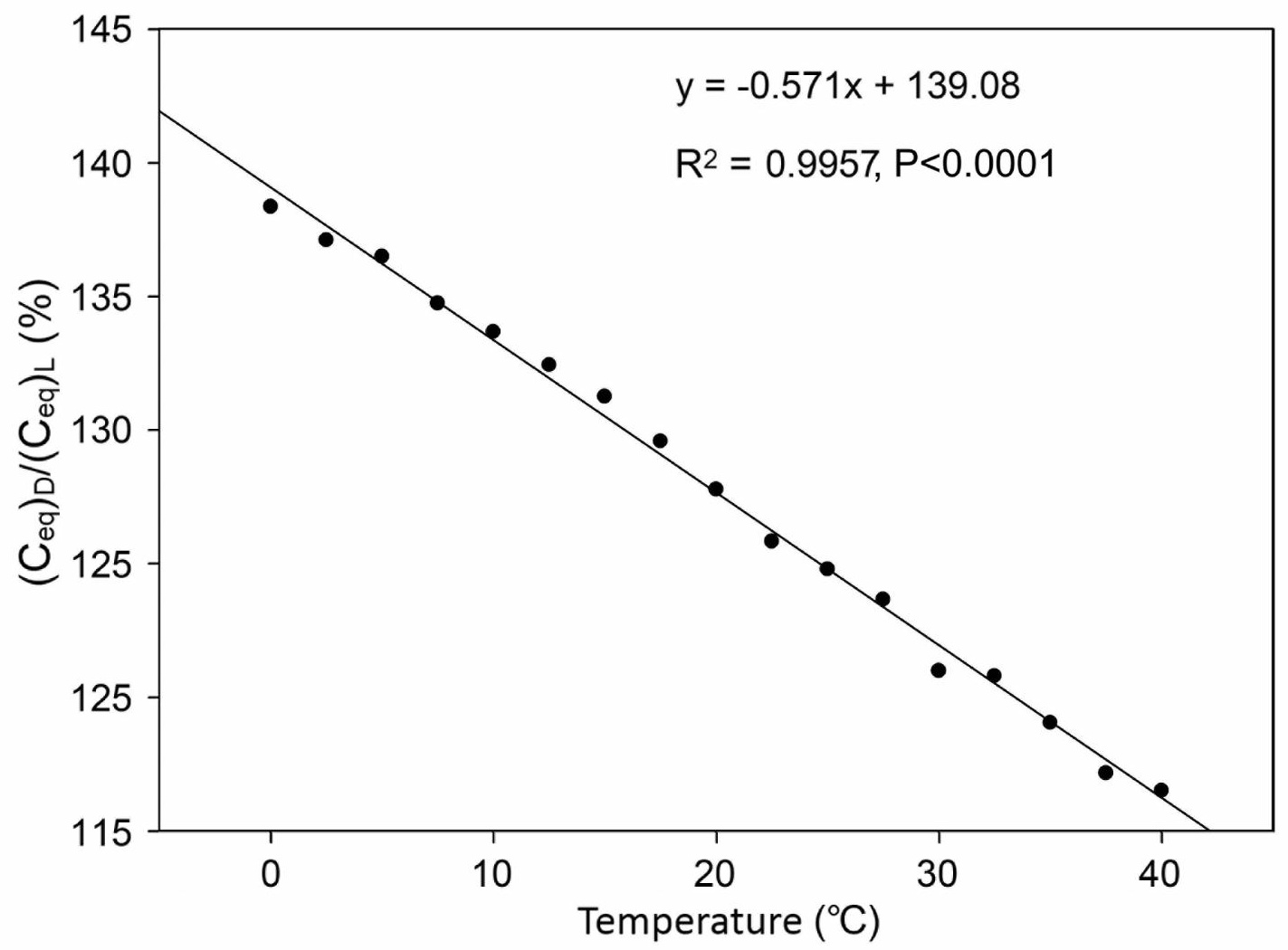



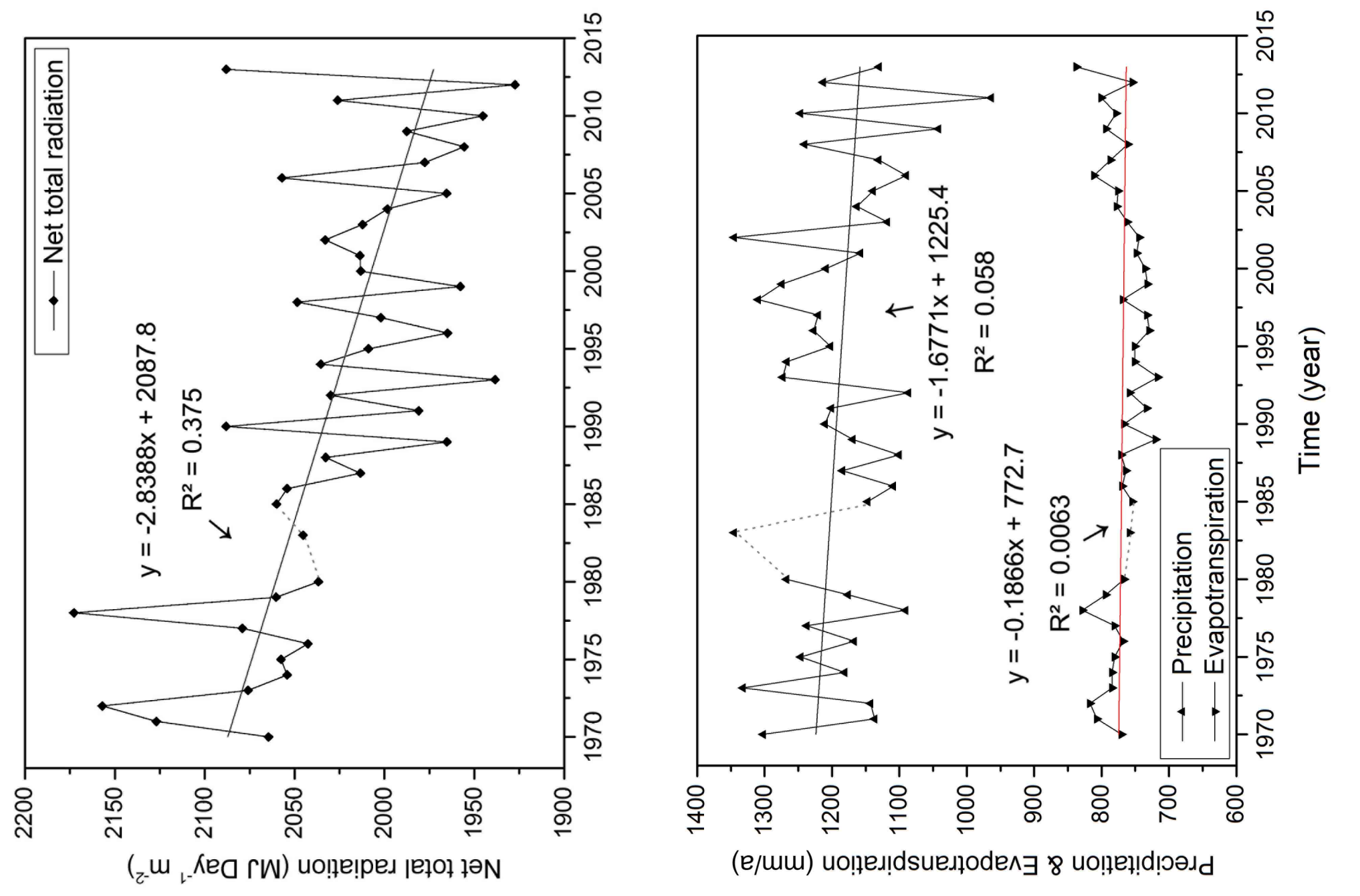

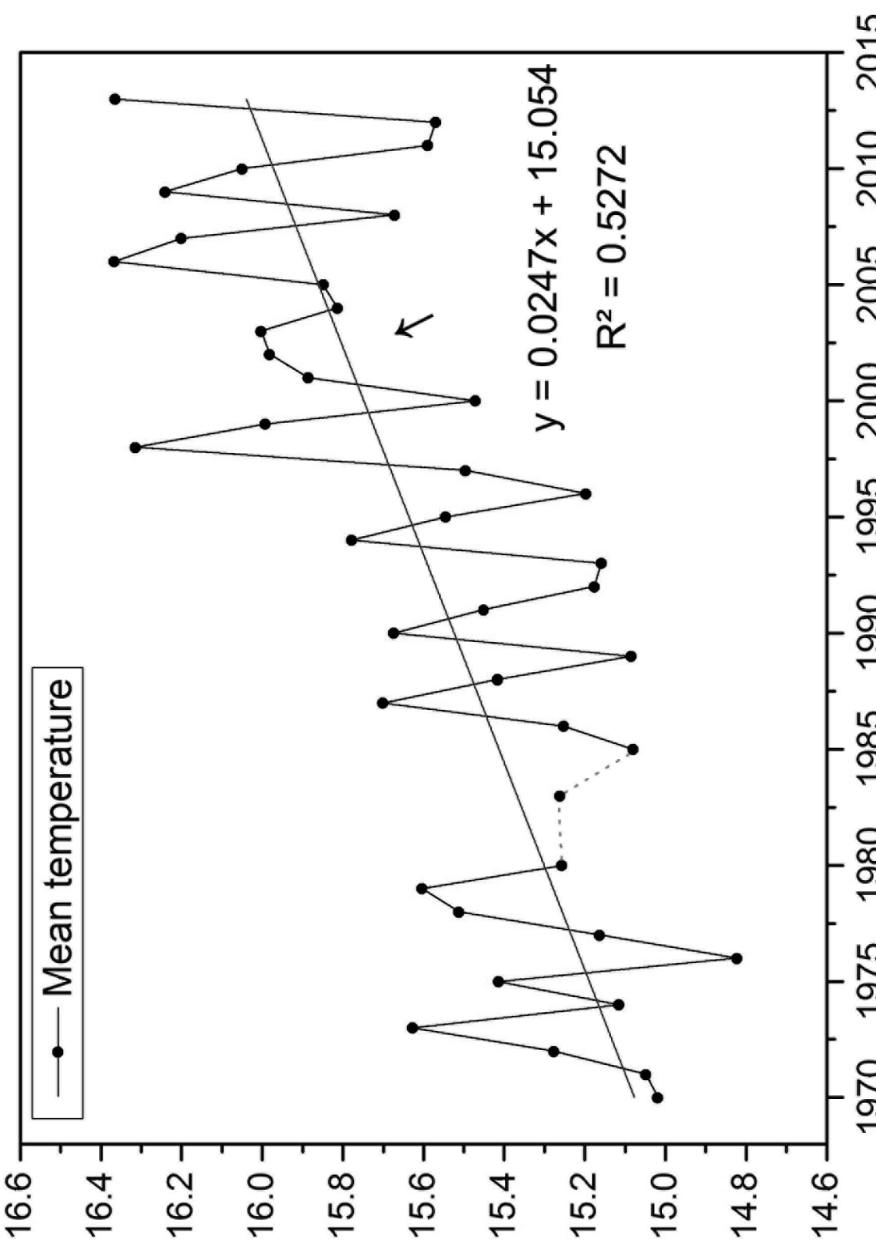

(๖) әınџеләdшәן иеәพ
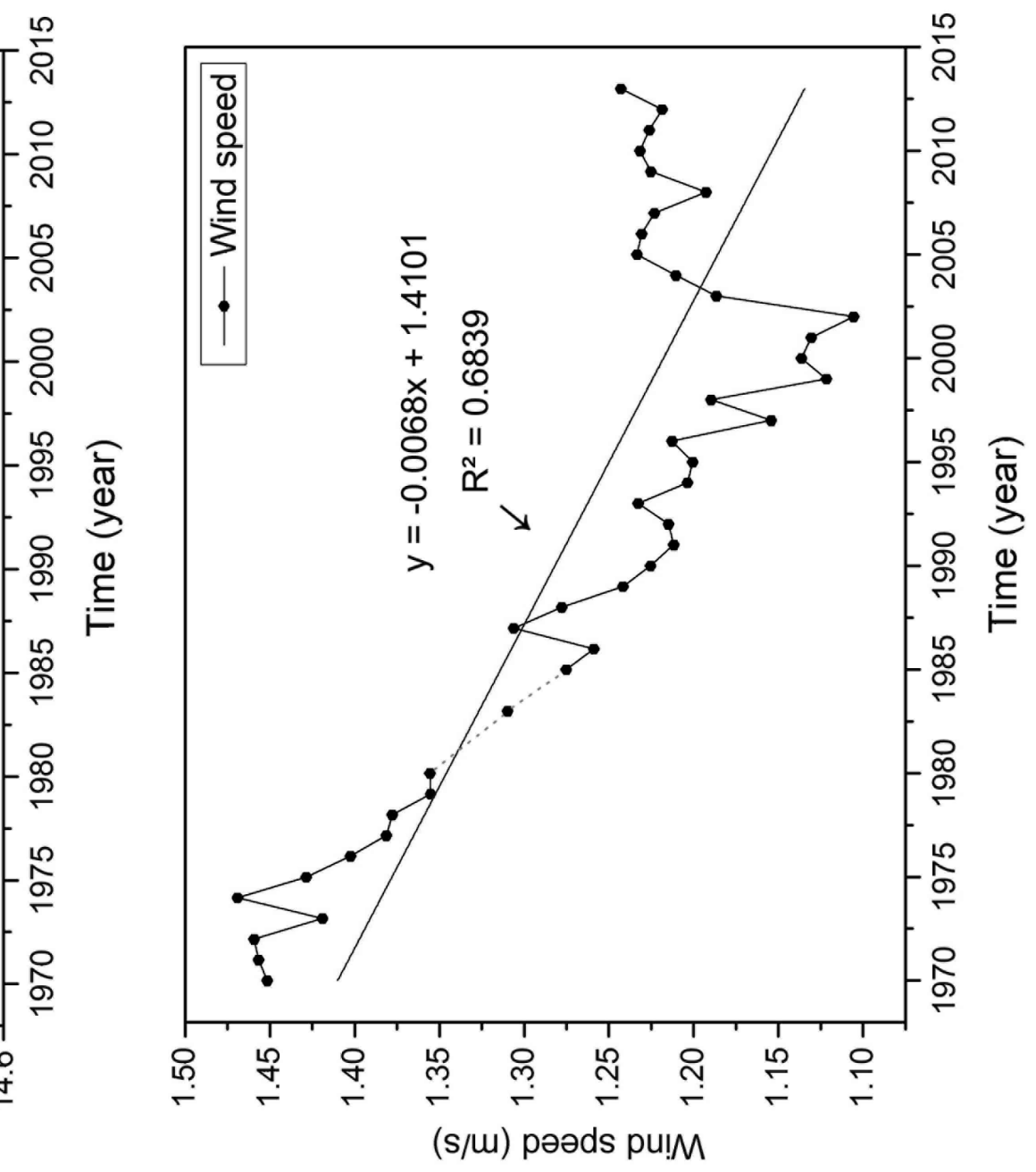


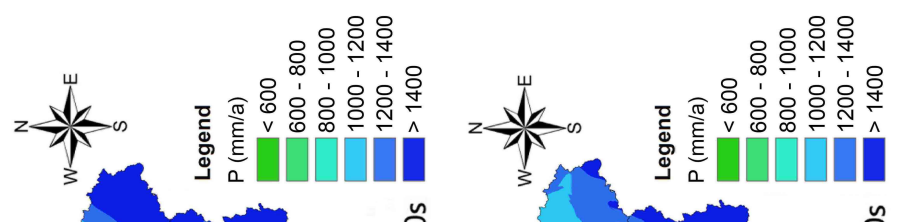

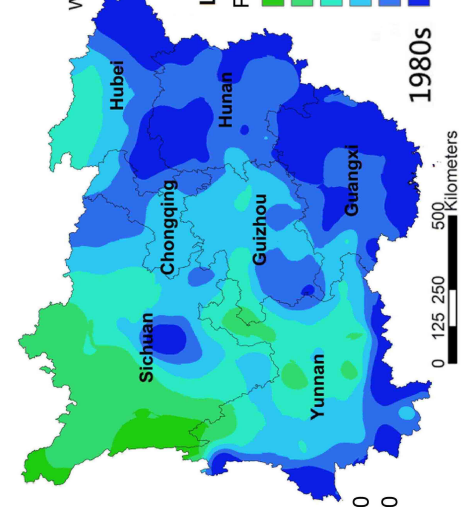

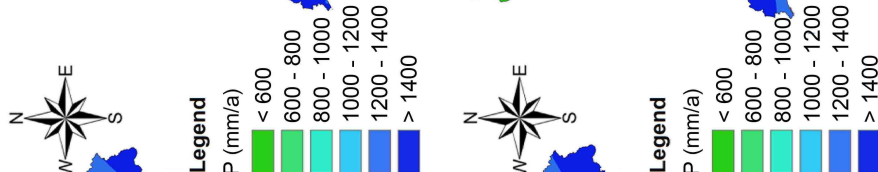
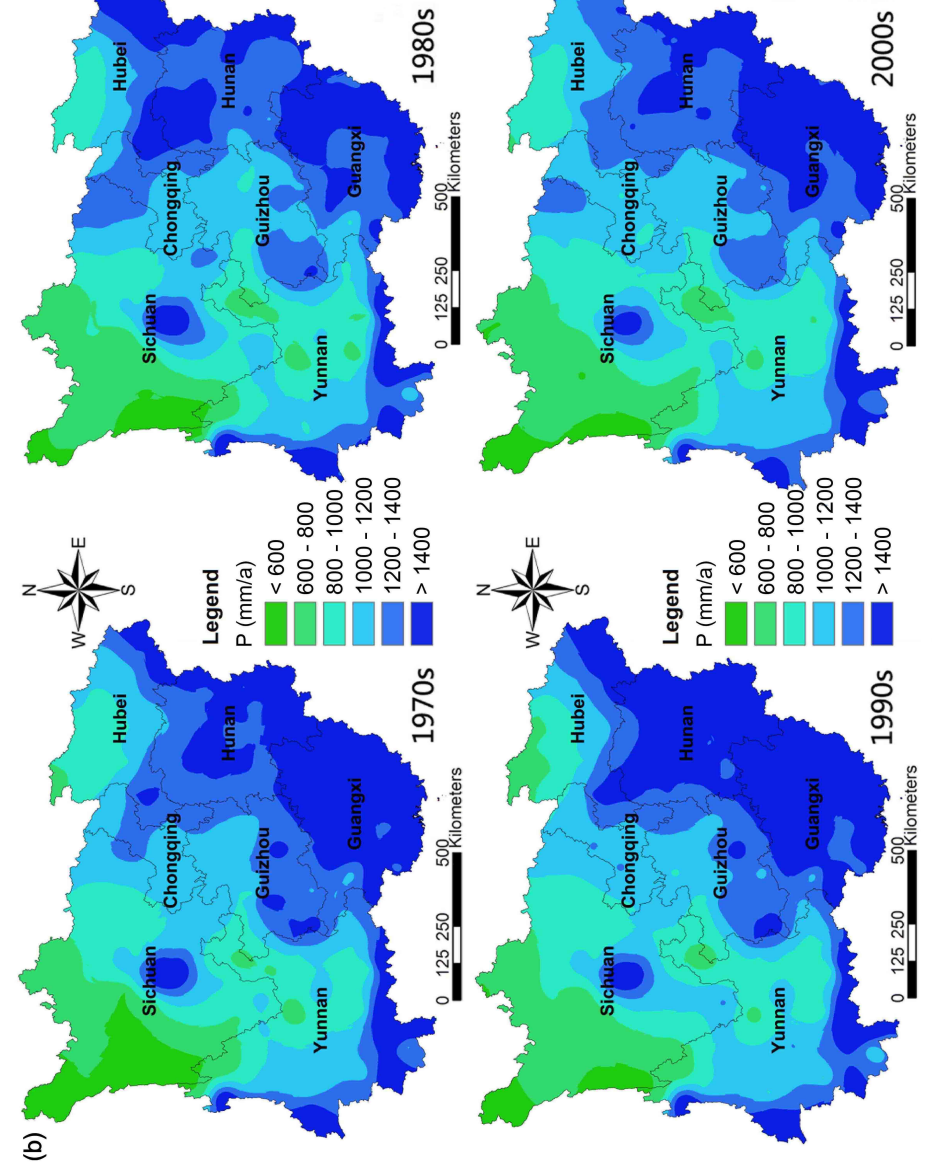

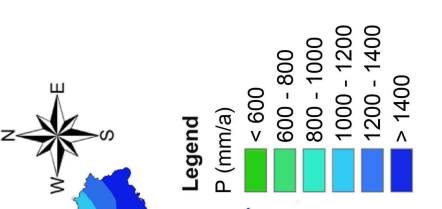

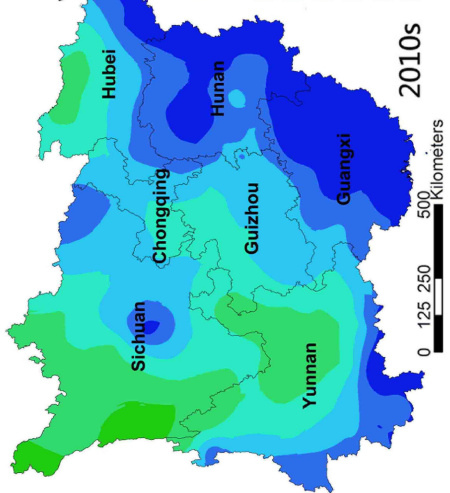

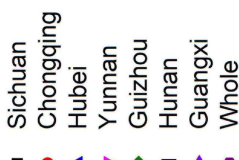
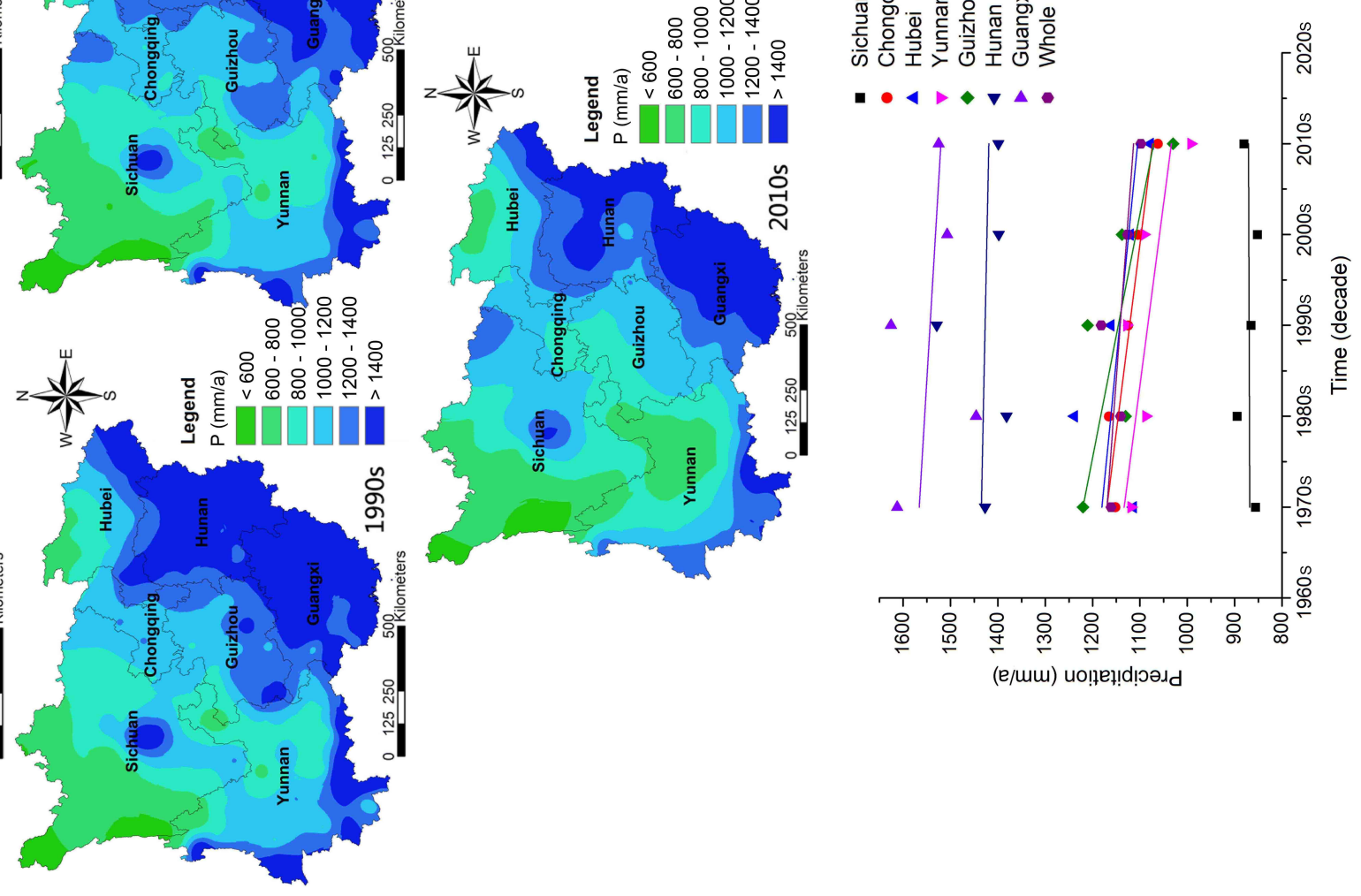

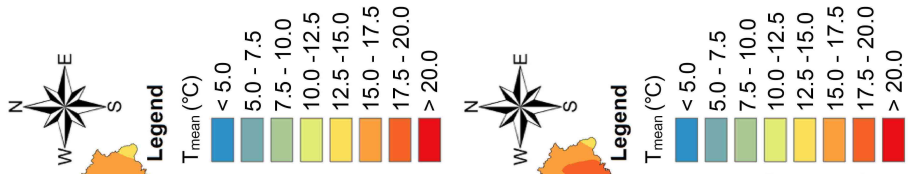

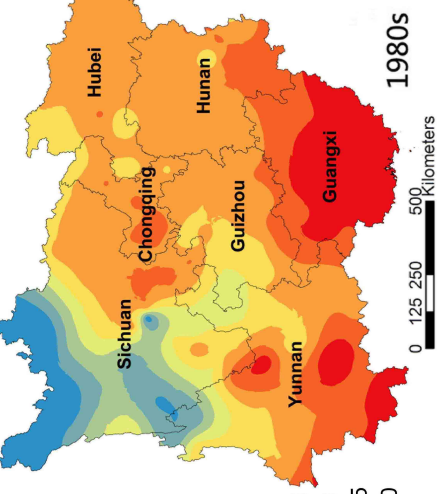

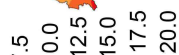

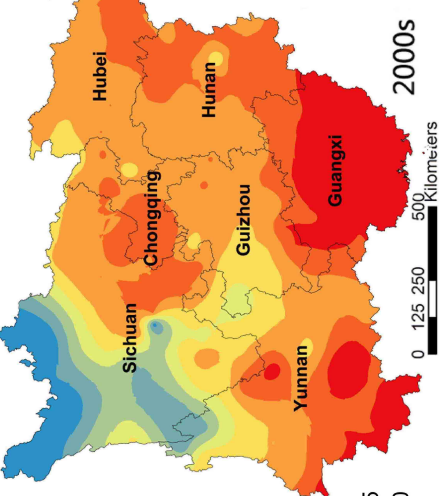

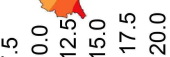

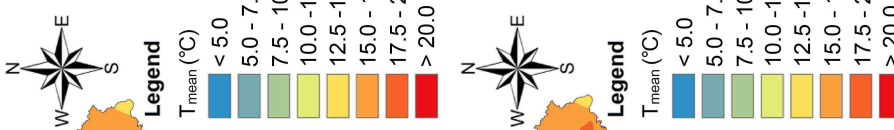
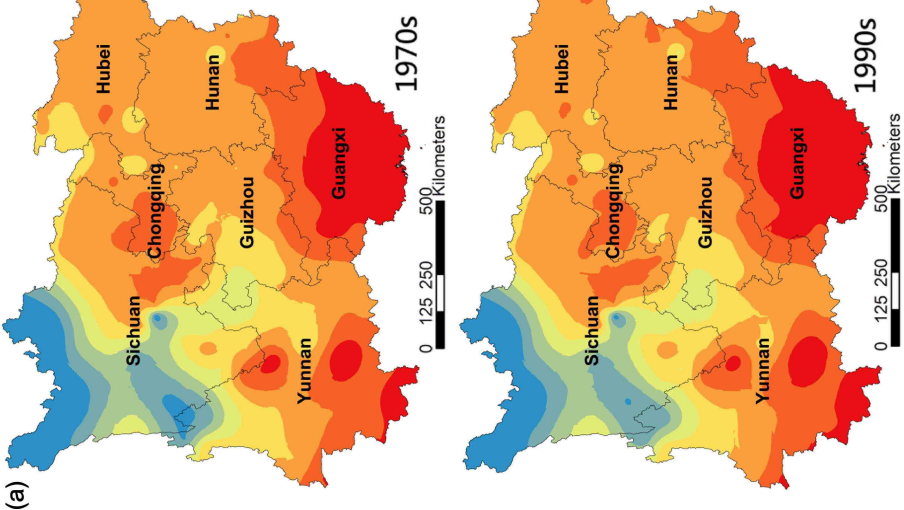

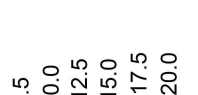

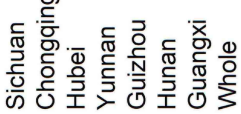

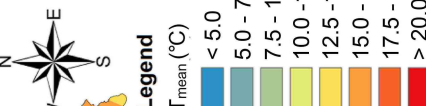
\{
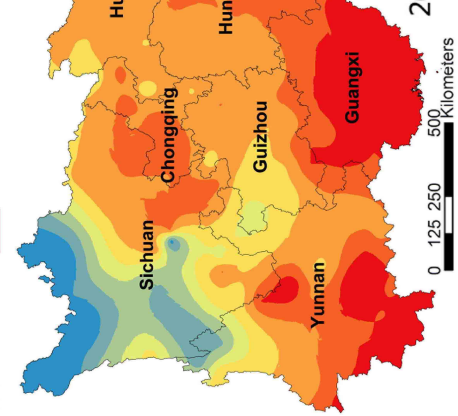

O





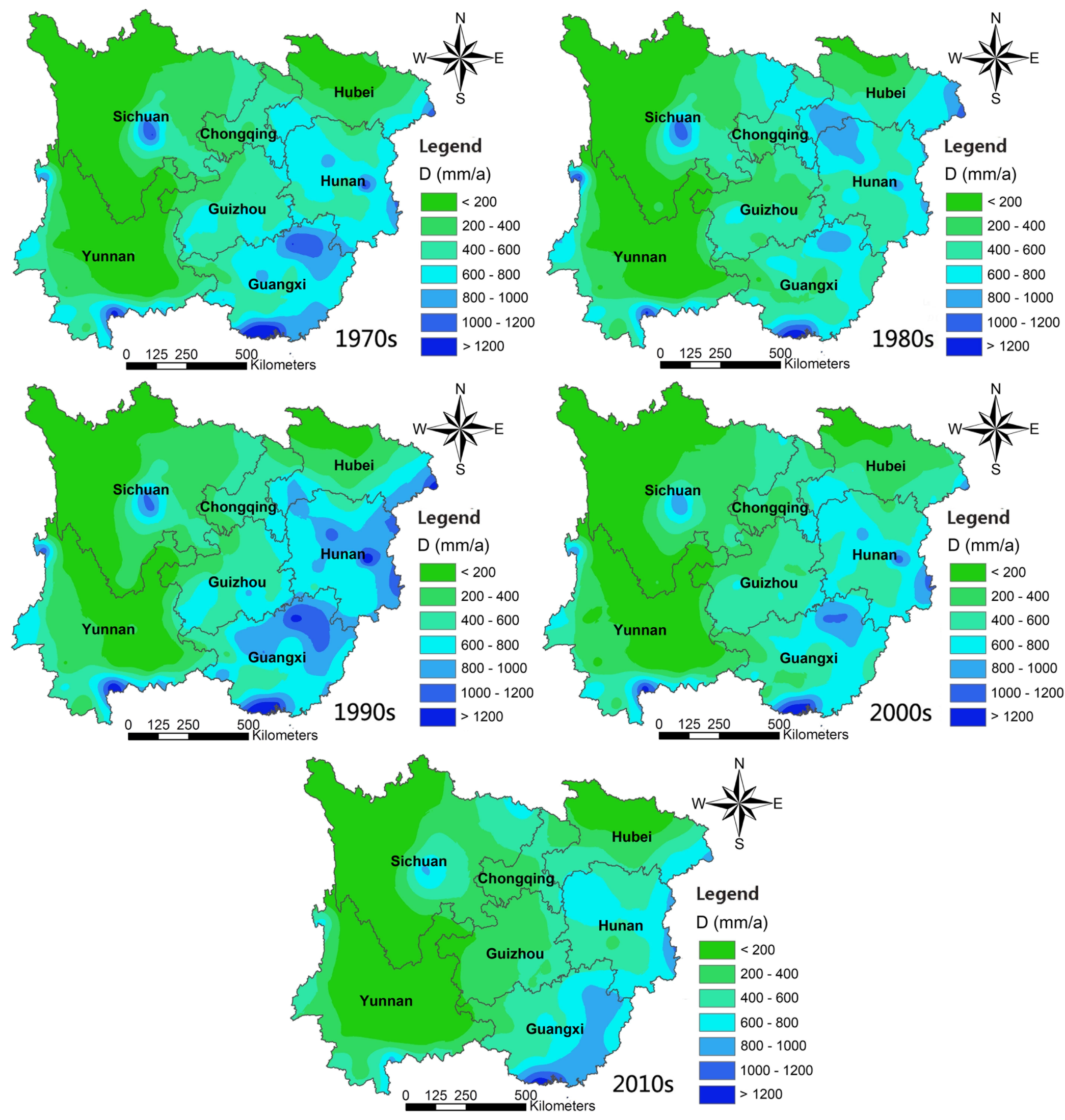

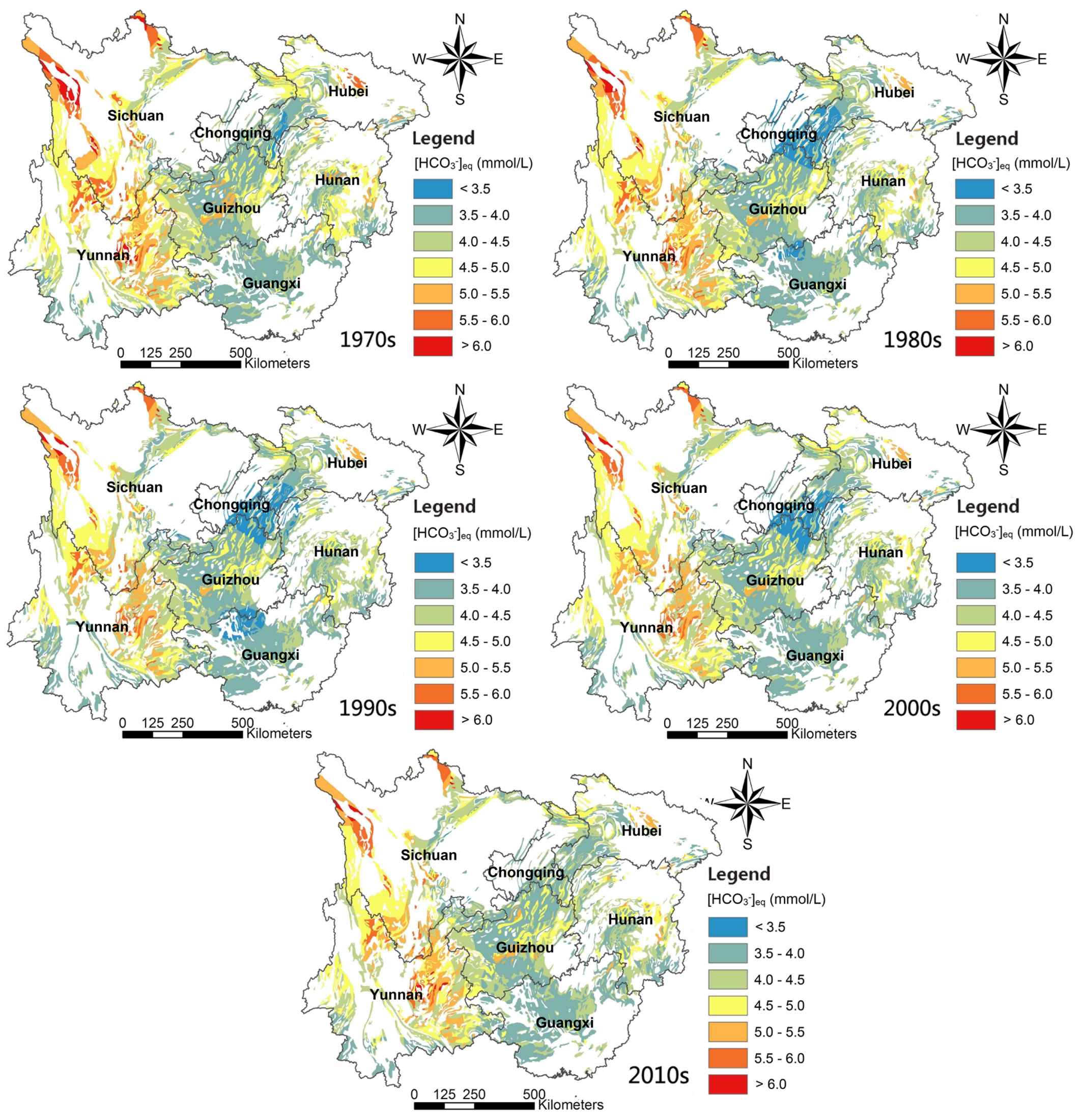







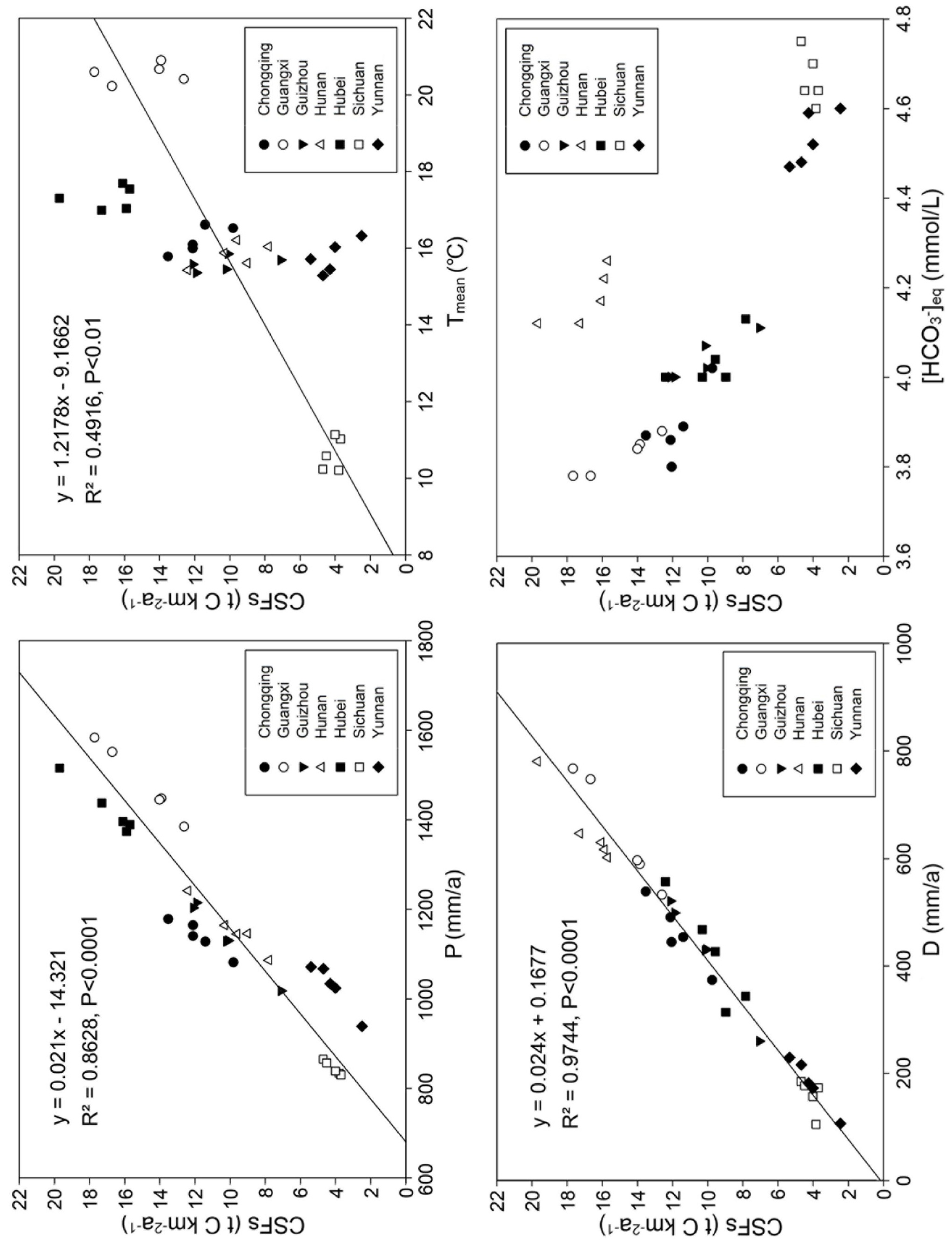


